\title{
The Influence of Police Training Programmes on Police Officers Participation in Environmental Sustainability Awareness in Uganda
}

\author{
Sseggiriinya Fredrick \\ Makerere University, Uganda \\ E-mail: sseggiriinyafredrick@yahoo.com
}

Ezati A. Betty

Makerere University, Uganda

Wafula Wcycliffscot

Makerere University, Uganda

Received: July 2, 2019 Accepted: October 10, 2019 Published: October 31, 2019

doi:10.5296/emsd.v8i4.15739 URL: https://doi.org/10.5296/emsd.v8i4.15739

\begin{abstract}
This study sought to investigate the influence of police training programmes on police officers participation in the environmental sustainability awareness in Uganda. The investigation was provoked by the reportedly deteriorating performance of police officers in areas of environmental sustainability awareness despite of government's effort to transform Uganda to a middle income country by 2040.The specific areas studied include influence of police training on their participation in community awareness in environmental sustainability awareness, police enforcement of environmental related laws and police officers participation in environmental sustainability. The study took an interpretive philosophical paradigm and was under pined by the Social learning theory and the Expectancy theory of Motivation. Data was collected using questionnaires, interviews, Focused Group Discussions, participant observation and documentary analysis. A total of 412 police officers and 80 non polices participated in the study. Quantitative data was analyzed using SPSS by use of descriptive statistics, correlation analysis, Regression analysis and Analysis of Variance (ANOVA) while qualitative data was analyzed using thematic analysis by use of transcription, coding and
\end{abstract}


themes development. The study findings showed a strong positive relationship between training programmes and police officers participation in environmental sustainability awareness, $(\mathrm{r}=0.587, \mathrm{p}=0.000, \mathrm{n}=412)$. It further showed that police training programmes are predictors of police officers participation in environmental sustainability awareness, $\mathrm{p}-\mathrm{v}$ $<0.050(=0.000)$. The relationship is statistically significant at $95 \%$ confidence level. The researcher concluded that police training programmes influence police officers participation in environmental sustainability awareness in Uganda. Thus it was recommended that police management promote community awareness on environmental sustainability awareness by allocating enough funds to standardize training and other activities related to environmental sustainability awareness in Uganda.

Keywords: Police Training Programmees, Environmental Sustainability Awareness

\section{Background to the Study}

The government of Uganda's vision is to have a transformed country to a middle income by 2040. This vision is in line with the United Nations Sustainable Development Goals 2030 and the African Union Agenda 2063. In order for these to happen, the environment must be used sustainably. This study sought to find out how police training programmes influence police officers' participation in the environmental sustainability awareness in Uganda.

\subsection{The Historical Background}

Policing has its origin in the" watch system" of the Middle Ages. The" watch system", was premised on voluntarily patrolling of the streets and guarding cities from sunset to sunrise. This period was characterized by lawlessness, corruption, theft, robbery, prostitution, among others (Paul. 2012). This lawlessness prompted citizen groups known as the vigilantes to spring up to combat crime.

According to Braton (2014), the first policemen, known as the "peelers" or "Boobies" were set up in London in 1829 by Robert Peel, the then home secretary, after the metropolitan police Act of 1829. These police officers were not formally trained but were guided by the following" nine peelers "principles as they are commonly known whenever on duty (1) prevent crime and disorder, (2) Their performance of duties was dependent upon public approval of the police actions, (3) secure the willing cooperation of the public in voluntary observance of the law to be able to secure and maintain respect of the public, (4) The degree of cooperation of the public diminishes proportionately to the necessity of the use of physical force, (5) Seek and preserve public favor not by catering to public opinion but by constantly demonstrating absolute impartial service to the law, (6) Police use physical force to the extent necessary to secure observance of the law or to restore order only when the exercise of persuasion, advice and warning is found to be insufficient, (7) at all times, should maintain a relationship with the public that gives reality to the historic tradition that the police are the public and the public are the police, the police being only members of the public who are paid to give full-time attention to duties which are incumbent on every citizen in the interests of community welfare and existence, (8) Should always direct their action strictly towards their functions and never appear to usurp the powers of the judiciary, (9) The test of police 
efficiency is the absence of crime and disorder, not the visible evidence of police action in dealing with it (Braton, 2014).

Over time, policing has been changing as many pre-civilized villages or communities developed rudimentary forms of law enforcement. As a result, there was a greater need for the proper training of police officers, especially in federal and state laws, evidence handling, prisoner transport, handcuffing, defensive tactics, firearms, driving, customer service and many other law enforcement as the quality of the police officers was poor in terms of training (Denham, 2008).

Walker (1977) observes that police education dates back in the $1^{\text {st }}$ century. During this period, there was kin policing with its penchant for blood feuding and traditions of tribal justice. In France, the first police training schools were established in Paris in 1883 and Bordeaux and Lyons in 1898. In Finland, the first police school was founded in Helsinki in 1918 (Pagon et al, 2017), advances that in. In Germany, as the states unified in 1870, each state became responsible for its own policing. In all these countries, police men were recruited from the army and the public and training included basic knowledge and military drills, writing dictation, theory of police work, conversations, correction of homework and telegraphy. The courses were compulsory and lasted for three months for literate and six to ten months for illiterate candidates. On completion of training, policemen were expected to use a telephone and telegraph, know their traffic island, laws and regulations to regulate traffic and conflicts and render artificial respiration, disperse the crowd and recognize the card of a diplomatic representative (Pagon et al 2017).

Stapleton (2015) report that pre-colonial Africa, due to diversity in societies did not have professional full time law enforcement organisations. However, every tribal community had its own systems of social control and policing method based on cultural norms and customary rules and obligations (UPF, 2014). The kings and chiefs policed the wide communities; the elders policed the villages while men policed their families. The elderly in general were responsible for enforcing discipline among the youth. Crimes were defined by the respective tribal community according to their agreed cultural norms and values. Punitive measures for cases of indiscipline were determined by a council of elders.

In Buganda, the Bambowa working on the orders of kings or chiefs (Mugagga, 2016) work apprehended criminal offenders and either took instant punitive action or took them for trial before the chief's court (Mukisa, 2013). The most reknown Mumbowa was called Mukajanga who executed the Uganda Martyrs. They were recruited from families which were believed to be royal to the Kabaka or chiefs while still young and their training was on job and continuous from the palace or the chiefs homes.

During colonial period, written laws were imposed and dedicated police forces created (Stapleton, 2015). The early colonial police forces were mainly paramilitary occupational armies, which violently enforced laws on forced labor and taxation. These later transformed into professional law enforcement organisations with better educated members. Recruitment was based on physical fitness and aggressive tendencies. Preferred qualities were people aged 17 to 25 years, height (not below 5 feet6 inches) and a chest size (not less than 33 inches) 
(UPF 2014). The course took eight months, some examinations were given and if a student was found unsuccessful he was dismissed outright by the commandant.

Captain W. F. A. Edwards the first Inspector General of Police in Uganda appointed on 25th may 1906 found that the Uganda Police Force were deficient in discipline, training and knowledge and that the training lacked uniformity (UPF, 2006). In 1923, Kibuli police training school was opened and train eight months in drill, weapon handling, law, police duties and procedures. Lessons were conducted in Kiswahili but reading and writing in English was encouraged.

\subsection{Conceptual Perspective}

In this study police training programmes was conceptualized as the initial or entry levels into the Uganda police force which is at four levels namely;

(1) Probationer police constable training for all those who are recruited and enlisted into Uganda police force as recruits' constable with ordinary or advanced level of education.

(2) Learner sergeants training course for those recruited into the force with specialized skills like nurses with a certificate level of education.

(3) Learner Assistant Inspectors training for those recruited into the force with specialized/ technical skills like engineering at a diploma level of education.

(4) Cadet Assistant Superintendents training for those recruited into the force with a University degree. All the above training programmes are meant to last for twelve months (Uganda Police Force Training Policy 2014). The researcher hoped that at all these levels police officers go through related curricula and initial training is compulsory for any police officer joining the Uganda Police Force.

The Cambridge English Dictionary $4^{\text {th }}$ edition defines Participation as to take part or become involved in something and awareness as knowledge or understanding of a subject. According to the Police Act Chapter 303 a police officer means any attested member of the police force.

Thus in this study, police officers participation in environmental sustainability awareness was conceptualized as any attested member of the Uganda Police Force taking part or becoming involved in disseminating knowledge and understanding about the importance of environmental sustainability

Therefore, the variables addressed in this study included Police Training Programmes as the independent variable and environmental sustainability awareness as the dependent variable. Environmental sustainability awareness was analyzed through levels of police officers enforcement of laws related to environment, police officers participation in environment sustainability activities, and police officers provision of environmental sustainability awareness to the community.

The European Quality Assurance in Vocational Education and Training(2008) define programme of education and training as an inventory of activities, content and /or methods implemented to achieve education or training objectives(acquiring knowledge, skills and/ or 
competences , aptitudes, abilities, understanding, attitude, and behavior),organized in a logical sequence over a specified period of time. Pagon .et al (1996) define police training as the process of imparting or acquiring particular knowledge or skills necessary for police work that does not lead to any kind of degree, but might (or might not) end with some form of certificate. This can be basic, specialized or management training.

In this study police training programmes means an inventory of activities, content and/or methods implemented to achieve police training objectives (acquiring/imparting knowledge, skills and/or competences), organized in a logical sequence over a specified period of time.

The focus was on initial/basic training because according to the Uganda Constitution (1995) as amended all police recruits must undergo initial police training. They go through the same curriculum irrespective of the entry level and according to (Uganda Police Force 2006, Police Act CAP 303), all police officers are mandated to undergo initial training. Thus the researcher hoped that improvement in their training basing on the findings and recommendations of this study would improve their participation in environmental sustainability awareness.

Environment is the sum total of water, air and land interrelationships among themselves and also with human beings, other living organisms and property, (United Nations Environmental ProgrammeUNEP 1999). According to the United Nations Commission on Economic Development (1987), sustainability is defined as meeting the needs of the present without compromising the ability of the future generations to meet their own goals. According to the National Environmental Management Authority, Uganda NEMA (2016) environment is related to land resources, water and wetland resources, atmospheric resources, and energy and mineral resources .Pachamama organization (2016) holds that environmental awareness is to understand the fragility of our environment and the importance of its protection. According to the Macmillan English Dictionary for Advanced learners, International Student Edition, awareness means knowledge, or understanding of a subject, issue or situation.

In this study, environmental sustainability awareness means creating knowledge, understanding and enforcing laws related to land, water and wetland, atmosphere, energy and mineral in order for the future generation to benefit from these resources. This will involve police participation in tree planting, clean where they stay and avoid environmental degradation.

\subsection{The Theoretical Perspective}

This study was underpinned by the Social learning theory introduced by Bandura, an American psychologist in 1977. Social learning theory states that "Individuals learn behavior by observing the others". Social Learning theory posits that people learn from one another via observation, imitation and modeling. The theory has often been called a bridge between behaviorist (which posits that learning is based on responses to environmental stimuli) and cognitive theories (which posits that learning is influenced by psychological factors). Social learning theory encompasses attention, memory and motivation. Bandura further states four meditational processes namely attention, retention, reproduction and motivation through which learning can occur (Mcleod. 2016, Hanna et al. 2014). 
Schunk in Kim (2001) explained that the best teaching and learning strategies associated with social learning theory are: Problem -Based learning, shared teaching, peer collaboration and learning with others. Simulations, virtual environments, gaming, scenarios among others are some of the best social learning and training strategies in police training that enhance police job performance. This means that learning is a cognitive process that takes place in a social context and can occur through observation or direct instruction.

To this study, this theory means that Police training programmes should enable trainees to observe, imitate and model the knowledge, understanding, skills; attitude and behavior of trainers in order to enable them participate in environmental sustainability awareness. This can be through the development of learning styles that develop trainees' attention, retention, reproduction, memory and motivation.

The Social learning theory needs another theory to enable police officers to participate in environmental sustainability awareness as Vroom (1964) advances that an employee's performance is based on individual's factors such as personality, skills, knowledge, experience and abilities. Thus the Expectancy theory of motivation was deemed necessary to supplement the social learning theory if police officers are to effectively participate in the social transformation in Uganda. This theory was developed by Victor Vroom in 1964 at Yale School of Management.

Expectancy theory of motivation suggests that our actions are based on our perception of what the outcome will be for our actions. This theory posits that Motivation (M) = Expectancy $(\mathrm{E})+$ Valance $(\mathrm{V})+$ Instrumentality (I). The bottom line is that the employee is going to yield out his maximum performance only if he believes that he will review certain achievable rewards for his performance (Shrestha 2017).

A study in U.S.A by Richard (2009) to test the ability of expectancy motivation theory to explain patrol officer drug arrest productivity, with the hope of identifying ways to influence patrol officer work outputs revealed that officers who produced the most drug arrests were more likely to have perceived that drug arrests were rewarded by their agency, perceived that management saw drug enforcement as a priority, received specialized training in drug interdiction, and perceived that they had sufficient time in their shift to properly investigate suspected drug offences .

Another study by Summerfeldt (2010) at Queensland University of Technology to verify factors influencing police work place motivation revealed five broad prime motivational factors that motivate police in their work. The prime motivational factors are: feeling valued achievements, work place relationships, the work itself and paying conditions.

In a related Study by Dejong et al (2001) to find out the relationship between patrol officers and problem -solving by application of expectancy theory revealed that officers who engage in more problem-solving are motivated by potential recognition of such behaviors. The study further revealed that expectancy motivation theory provides a more likely explanation for the behavior of community police officers than that of traditional "beat" officers. Ddamulira (2009) argues that promotions have an inducement towards the members of the Uganda 
Police Force especially owing to the fact that they always attribute it to good payoff and general increased good welfare and standards of living.

To this study, this theory means that police officers will effectively participate in environmental sustainability awareness in Uganda if they expect Motivation. This motivation can either be in terms of monitory like better salaries and allowances or non-monitory like promotions and other resources that enable effective participation.

\subsection{Contextual Perspective}

The study was carried out in Uganda. The emphasis was on how initial training programmes enable police officers to participate in environmental sustainability awareness in Uganda. According to the UPF training policy (2014), the objectives of training are:

i. Keeping up to date and enhancing professionalism, knowledge and skills needed for better performance of the individuals and the organization.

ii. Promoting better understanding about professional, social-economic, cultural, political, and technological and environments in which police work is done

iii. Bring about right attitudinal, behavioral and ideological orientation among police officers.

iv. Promoting and understanding of inter departmental linkages within the force and other stakeholders in maintenance of law and order.

These objectives are in line with the functions of the Uganda Police Force as enshrined in the (1995) Constitution of the Republic of Uganda as amended, namely:

1. To protect life and property.

2. To preserve law and order.

3. To prevent and detect crime

4. To cooperate with the civilian authority and other security organs established under this Constitution and with the population generally.

According to the Uganda Constitution (1995) as amended, members of the Uganda Police Force are supposed to be nationalistic, patriotic, professional, disciplined, competent and productive, and its members to be citizens of Uganda of good character. Despite of the above clear police training objectives and functions, research show that Uganda's environment is facing so many challenges like land degradation, deforestation, extinction of some mammalian species, overfishing, reclamation of wetlands for agriculture, high rate fuel wood consumption(National Environmental Management Authority 2016), yet the Uganda police force has departments which deal with the environment (environmental protection police unit), fisheries (police marines), police Land protection unit, and there are many police officers attached to the ministry of agriculture, animal industry and fisheries (Uganda Police Force 2015). It is important to note that, improvement in environmental sustainability awareness is one of the recipes for development. Failure of police training programmes to positively impact this area will affect the pace of development 


\section{MlMacrothink}

\subsection{Statement of the Problem}

According to the Uganda police Force training policy (2014) and the Uganda Police Force curricula for Probationer police constables (2015), and Cadets/ assistant superintendents of police (2015), police officers go through rigorous initial training. Upon graduation, they are expected to participate into environmental sustainability awareness (Uganda National Environment Management Authority. 2002, Uganda Police Force Curriculum for Probationer Police Constables. 2015, \& Uganda Police Force Curriculum for Cadet Assistant Superintendents of Police. 2015). However, their performance on graduation seems not in tandem with what they are taught. For example Uganda's environment is continuously being destroyed (National Environmental Management Authority Report 2016). Failure to address these weaknesses will not only worsen environmental sustainability but will hinder the achievement of vision 2040 of a middle income country. Could the weaknesses in police performance in environmental sustainability be related to their training?

\subsection{Purpose of the Study}

The purpose of this study was to analyze the influence of police training programmes on police officers participation in environmental sustainability awareness in Uganda.

\subsection{Objective of the Study}

The objective of the study was to:-

(i) To find out the influence of training programmes on police officers' provision of environmental sustainability awareness to the community in Uganda.

\subsection{Hypothesis}

The following research hypothesis guided this study

Police training programmes influence police participation in environmental sustainability awareness.

\subsection{Scope of the Study}

Geographically, the study was conducted in Uganda. Efforts were made to get representations from all the districts of Uganda where police graduates of 2010 and 2014 have been deployed. Only initial police training programmes courses in the Uganda Police Force were investigated because they are designed for all new entrants into the Uganda Police Force irrespective of the level of entry. This study was carried out between 2014 -2019. The study looked at only police officers participation in the environmental sustainability awareness in Uganda.

1.10 Conceptual Frame Work of the Influence of Police Training Programmes on Police

Officers participation in environmental sustainability awareness 


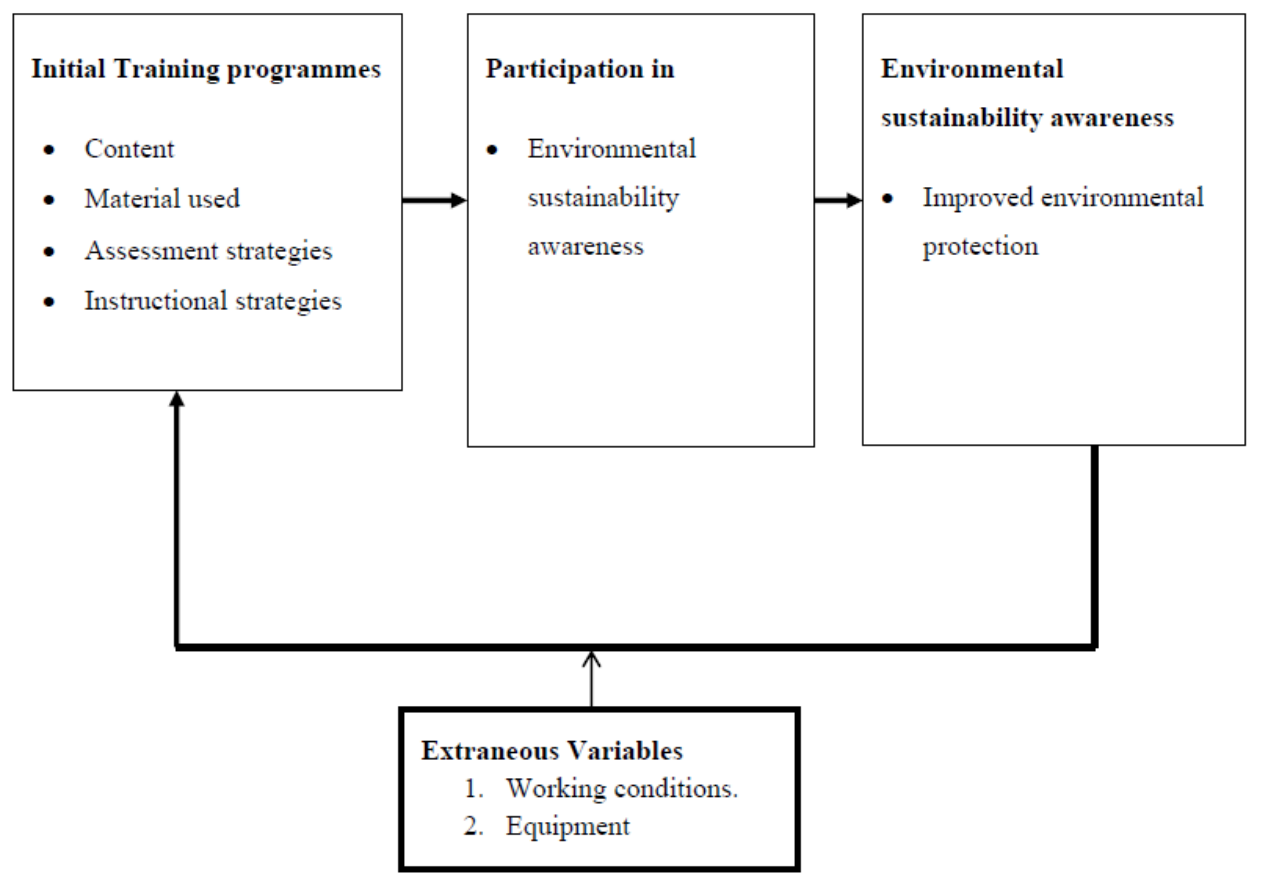

Figure 1. Conceptual framework of the influence of police training programmes on police officers participation in environmental sustainability awareness

Source: model self-constructed by the researcher

The study variables include police training programmes as the independent variable. The indicators of this variable are highlighted as content, instructional strategies, materials used, assessment strategies and training methods of the initial police training programmes and environmental sustainability awareness as the dependent variable. The indicator of the dependent variable is indicated as improved environmental protection in Uganda.

The conceptual framework shows that relevant and adequate content, materials used, assessment strategies and instructional methods/ strategies will produce graduates who are able to participate in ESA. However, if this is not then the graduates would not effectively participate in towards ESA of Uganda. In this study, the extraneous variable that could possibly influence PTPs is the working conditions such as infrastructures like offices and equipment such as vehicles, computers, cameras and printers.

\section{Related Literature}

\subsection{Police Training Programmes and Promotion of Environmental Sustainability Awareness}

According to UN (2014) enforcement of environmental laws, good practices from Africa, central Asia, Asean Countries and China reveal that" enforcement of environmental laws and regulations differ from one country to another and from one continent to another". This provides opportunities to learn from each other and the study breaks enforcement into three categories: (1) administrative enforcement. (2) Civil enforcement (3) criminal enforcement. 
Administrative enforcement includes (a) institutional coordination/ collaboration,(b) information sharing and knowledge management,(c) tools, equipment and training,(d) awareness and public engagement. Civil enforcement includes (a) tools, equipment, and training,(b) procedures (c) awareness and public engagement(d)information sharing and knowledge management, (e) alternative dispute resolution. Criminal enforcement includes (a) institutional coordination/ collaboration, (b) tools, equipment training and information sharing and knowledge management, (c) awareness and public engagement, (d) procedures in the criminal law, and (e) remedies (criminal sanctions and penalties).

The above are relevant and correct revelations and suggestions but did not look at how police training programmes in Uganda prepare the police officers for the provision of the afore mentioned tasks. This study thought to address this gap.

A study by Stravoot and Rawang (2016), in Thailand to investigate the integration of environmental education and environmental law enforcement for police officers to improve the efficiency of functional competency for police officers in Bangkok Metropolitan Police Division 9 revealed that," most Thai police officers were knowledgeable and skillful in environmental law enforcement, but low actualization on their role and responsibilities for education to preserve natural resources and environments". The study suggested that most police officers needed to obtain the environmental education to inspire their empowerment before performing the environmental law enforcement. This would improve their functional competency on natural and environmental conservation.

This study developed an integrated model with six main factors to enable police officers perform in natural resources and environmental law enforcement. The six factors are: (1) environmental education, concept, principle, objective, approach, resource and evaluation, (2) policy, (3) leadership, (4) incentive, finance and non-finance resource allocation, (5) networking with environmentalists and non-environmentalists, (6) environmental law enforcement, knowledge and practice. This model was found to be effective after testing it on 50police officers. Thus if used in police training programmes in Uganda, police officers could effectively participate in ESA.

The study took a mixed methods research design, data was collected by use of questionnaires, interviews, focused group discussions. Data was analyzed by percentages, mean scores, standard deviation and tables.

A related study by Wunderlich (2017) to investigate the structure and law enforcement of environmental police in china revealed that "the environmental protection bureau has limited power, the police structure is complex, and the structure of environmental governance in China is fragmented". These impede inter-departmental cooperation, low levels of public participation, and lack of capacity and personnel. The study suggested that the Chinese environmental police needs a superior legal status and the environmental police are a legal police force. Should the recommendations of this study implemented in Uganda, Police officer will effectively participate in ESA.

Alm and Shimshack (2014) investigated Environmental enforcement and compliance lessons 
from pollution, safety and tax settings in U.S.A. The investigation revealed that" although traditional environmental monitoring and enforcement actions generate important deterrence effects, there are limits to such deterrence, meaning that deterrence itself cannot fully explain all patterns of environmental behavior". The study suggested that encouraging compliance requires both traditional and additional tools; this implies that even in Uganda police participation in ESA requires both traditional and additional tools.

Gunningham (2011) study in U.S.A on enforcing environmental regulations revealed that, for environmental regulations to work" they must not only be well designed but also efficiently and effectively enforced". The study further reveals that "strategies should go about the task of intervening in the affairs of regulated organisations to ensure compliance and enforcement". The study took descriptive, analytical and normative approaches to explore the practices of a representative sample of environmental regulators while identifying a number of distinctive intervention strategies which are only limited by existing theoretical models.

The study recommended that:(1) resource allocation through risk based regulation be adapted. This involves the development of decision-making frame works and procedures to priorities regulatory activities and deploys resources principally relating to inspection and enforcement, based on assessment of risks that regulated organisations pose to the regulator's objectives.(2) The following intervention strategies be adapted (a) rules and deterrence, (b) advice and persuasion, (c) criteria Based regulation, (d) responsive regulation, (d) smart regulations , (e) risk-based regulation and(f) Meta-regulation/hybrid regulation. However, the fore going study was carried from outside Uganda, not fully police based and carried out almost six years ago. These constitute gaps namely of conducting a similar study in Uganda, thus a justification for this study.

A related study by Brennan (2016) in Northern Ireland on the enforcement of waste law: Deterrence, Damping and the Dynamics of Devolution suggested that" a significant shift in enforcement culture and practice in Northern Ireland is necessary in order to ensure enforcement action against Waste criminals is effective". The study further suggested for fundamental structural changes in the architecture of environmental regulation. Therefore Uganda could have fundamental structural changes in the architecture of environmental regulation if police is to effectively participate in ESA.

Cao and Shao (2017) analysis of environmental law enforcement mechanisms based on economic principles in China revealed that "strengthening and improving the environment law enforcement mechanisms is an important way to protect the ecological environment". The researchers suggested that full mobilization of all aspects of environment law enforcement such as legislative bodies, law enforcement agencies, public welfare organizations, televisions, newspapers, enterprises is necessary. They also suggested the use of other various management means such as government regulation, legal sanctions, fines, persuasion and denouncement. The formation of an organic structural system was suggested in this study as a mechanism to enforce environmental law basing on economic principles in China.

This study was based on economic principles by making an analysis of the marginal costs 
using Pigou means and the Marginal transaction costs by using Coase means vary with the quantity growth of pollutant discharge enterprise. The findings and suggestions of the studies above are varied but were carried from outside Uganda and are not education based in nature. This constitutes a gap of a similar study in Uganda which is education based, thus a justification for this study to close this gap.

Basing on the reviewed literature above, there is evidence that police training programmes enable police officers promotion of ESA. Therefore, police should emphasize it in its training.

\section{Methodology}

\subsection{Research Approach}

The researcher adopted an interpretivism philosophy; this is a school of thought that focuses on meaning of social interaction. According to Chowdbury (2014) Interpretivist philosophy claims that social reality is different from natural reality because the subjects of social realty are human beings and their relations with each other. Therefore, human interactions are likely to create various interpretation of reality.

The researcher adapted this philosophical orientation in this study for three reasons: first, to understand and interpret correctly the influence of police training programmes on police officers, participation in the environmental sustainability awareness of Uganda and other stake holders' views rather than generalizing and predicting the influence of police officers participation in the environmental sustainability awareness in Uganda.

Secondly, the researcher wanted police officers' and members of public analysis of police training programmes influence on the police officers participation in environmental sustainability awareness of Uganda in depth because of the different cross cultural, social, economic and political backgrounds in Uganda and police organization. Thirdly, the researcher believed that primary data generated via interpretivism is associated with a high level of validity because of the ethical considerations in this study.

In view of the above, the philosophical underpinnings in this study are discussed as follows: The researcher believes that reality (ontology) is subjective, have multiple meanings and none of them is more varied than the other as seen by the participants in an Interpretivist assumption (Konstantin 2014). There are many different meanings in the world and none of them is more valid than another (Gay \&Airasian, 2003). This befits my understanding that the influence of police training programmes on environmental sustainability awareness in Uganda/ is interpreted differently by various people and none of the interpretations is more valid than another.

Epistemological assumption (What constitutes valid knowledge), researcher interacts with that being researched in an Interpretivist assumption (Konstantin 2014). Gall, Gall and Borg (2003) argue that the features of social environment are constructed as interpretations by individuals and that these interpretations tend to be transitory and situational. In this study, the researcher interacted with the participants through interviews, FGDs and during 
questionnaires administration. The researcher made efforts to interpret the findings in this study.

Axiological assumption (the role of values), Researcher acknowledges that research is value -laden and biases are present in an Interpretivist assumption (Konstantin 2014). To avoid biases in this study, and to show the value the researcher attached to this study, various methods to collect data were used. Findings are reported as they were obtained without being interfered with by the researcher's value- laden system and other ethical considerations in this study were considered.

Rhetorical assumption (the language of research), the researcher writes in an informal style and uses the personal voice, accepted qualitative terms and limited definitions in an interpretive study (Konstantin, 2014).In this study verbatisms' and quotations from some respondents were used in some instances to report the findings. The thesis is written with few definitions apart from the conceptualization definitions. An interpretation of the findings was done as a personal voice of the researcher.

Methodological assumption (the process of research). Konstantin (2014) posits that in an interpretive philosophical paradigm, the process is inductive, study of mutual simultaneous, shaping of factors with an emerging design/ categories are identified during the process, research is context bound, patterns and or theories are developed for understanding, findings are accurate and reliable through verification. In this study the researcher maintained the ethical considerations in research throughout to ensure that the findings are accurate and reliable. Qualitative and Quantitative data control measures were ensured for the same purpose in this study. Therefore Interpretivism philosophy helped the researcher to analyze how trainees use what they have learnt to transform society by participating in areas of environmental sustainability awareness.

Thus in this study, the constructs of the influence of police training programmes on the police officers participation in the environmental sustainability of Uganda were obtained and measured subjectively using a self-administered questionnaire, interviews, Focused Group Discussions, Documentary analysis and Observation checklists.

In addition, the researcher adopted a mixed method approach in this study incognizant of Wisdom and Creswell (2013) who contend that mixed method refers to an emergent methodology of research that advances the systematic integration or mixing of quantitative and qualitative data within a single investigation or sustained program of Inquiry. The basic premise of this methodology is that such integration permits a more complete synergistic utilization of data than do separate Quantitative and Qualitative data collection and analysis.

The researcher adapted mixed methods because he believes that it was an ideal technique to assess complex situations in police training programmes in Uganda as it enabled the researcher to make relevant, timely and applicable working interventions into police training programmes in Uganda that might enhance their participation in environmental sustainability awareness.

Mixed methods also helped the researcher to validate the findings got from police graduates 
using quantitative method with findings got from members of public, community leaders, district leaders, police training administrators, district police leaders, government and non-government organisations using qualitative data sources.

Lastly, mixed methods helped the researcher in developing a survey instrument that brought out data which would have been left out in a single based survey instrument regarding police training programmes and their influence on police officers' participation in the environmental sustainability awareness in Uganda. However, the researcher got some challenges while using a mixed approach in this study such as the complexity during data analysis, looking for additional resources to complete the work and time for data presentation was prolonged despite of it being adopted .These challenges were overcome by the researcher insisting on the conventional methods of data analysis in a mixed study. The researcher also got a loan and a study leave.

\subsection{Research Design}

An interpretive approach and a survey design were adapted in this study. This was because the researcher wanted to focus on an area where he has intrinsic interest and in this study the researcher's interest was on the influence of Police training programmes on the police officers participation in environmental sustainability awareness in Uganda. In addition, the researcher wanted to analyze data within and across settings, to understand unique and critical cases, and getting an in-depth understanding of the influence of Police training programmes on the police officers participation in the environmental sustainability awareness of Uganda.

The researcher attempted to understand, describe and interpret the transformation and behavior of the police officers after their initial Police training programmes and how various members of public assess police officers' participation in environmental sustainability awareness promotion in Uganda. Whereas a survey design was used in this study, it was costly in terms of money and time because it required the researcher to move to different parts of the country where the respondents were situated. To deal with this challenge, the researcher utilized the money budgeted sparingly and used the time by getting a study leave during this study.

\subsection{Parent Population and Target Population}

In this study, the parent population was all cohorts of 2010 and 2014 police officers, staff of police training schools, leadership of police force in Uganda, and members of public. According to the Uganda Police Force Strategic Policing Plan 2015/16-2019/20, the Uganda Police Force personnel strength stood at 44,601 officers by May 2016.

The researcher hoped that the cohorts of 2010 and 2014 had gone through the same curriculum at probationer police constables .It was further believed that cadet assistant superintendents of police had gone through the same curriculum at their level, had started assuming leadership positions within the Uganda Police Force and had been in the field for more than five years, so they could easily assess if their initial training enables them to participate in environmental sustainability awareness. The researcher also believed that staff 
of police training schools is in a better position to evaluate whether the content, materials used, assessment and instructional strategies used during initial police training programmes facilitate graduates' participation in Environmental Sustainability Awareness ( ESA), in Uganda. Leadership of Uganda Police Force (UPF) is the policy maker; therefore its opinion on Police Training Programmes (PTPs) was needed. Members of public were included in this study because they are the beneficiary of the police services; their independent opinions would further make a better understanding of the influence of police training programmes on police officers participation in the studied areas.

\subsection{Sample Size}

In this study, respondents were drawn from police training schools, police stations and selected District leaders and members of public, Non-Government Organizations, Government ministries and Departments as indicated in Table 1. In this study a total of 450 police officers and 100 members of public participated in this study. Therefore, a total of 550 respondents participated in this study. The researcher took cognizant of this and hoped this was adequate to suffice the confidence level $=95 \%$ and Margin of Error $=+$ or $-5 \%$ for this study.

For the known population sizes, the sample size was determined in three ways. (1)Krejcie and Morgan (1970) sample size determining table, (2) Effect size, which according to Statistical Solutions (2019) is the difference between the sample statistics divided by the standard error while using correlation coefficient. Cohen $(1988,1992)$ advances that the value of the effect size of Pearson $r$ correlation varies between -1 to +1 . Furthermore, Cohen $(1988,1992)$ suggests that the effect size is low if the value of $r$ varies around 0.1 , medium if $r$ varies around 0.3 , and large if $r$ varies more than 0.5 . Thus since a sample size of 80 gave $r$ value of 0.88 , the researcher regarded it as a large sample size for non-police officers in this study, and (3) by using sample size calculator, according to Creative Research Systems (2012), sample size calculator gives a confidence level of $95 \%$ or $99 \%$, a confidence interval (Margin of error of +5 or -5 of the population). In view of this, the researcher adapted it in determining the sample sizes of known populations in this study.

For unknown population, the sample size was delivered by computing the minimum sample size. This was by considering the standard normal deviation set at $95 \%$ confidence level (1.96), percentage picking choice or response $(50 \%=0.5)$ and the confidence interval $(0.05=$ + or -5$)$. Thus the formula

$\mathrm{N}=\mathrm{Z} 2(\mathrm{p})(1-\mathrm{p})$

C2 was used, where

$\mathrm{Z}=$ Standard normal deviation set at $95 \%$ confidence level,

$\mathrm{P}=$ Percentage picking a choice or response,

$\mathrm{C}=$ Confidence interval

The sample included 7Police training school administrators from 5 schools, 25 instructors 
from each of the five police training schools, 112 police graduates from intake 2010 and 112 from the intake of 2014 because had gone through the same curriculum and had stayed in the field for at least five years,5 District police leaders from the 5districts where the police training schools are found ,99members of community , ( 4 community leaders from five Districts , 4Districts leaders who included the Resident District Commissioner, the Chief Administrative Officer, The District Internal Security Officer and the Chairperson Local Council Five, 4 members of community from the five districts where these schools are found,2 from 5 government ministries and departments and 2 from 5 Non-Government Organizations. 1n total 381 police officers and80 members of community participated in this study. The police officers from cohort of 2010 and 2014 were selected using Snowball technique. Attempt was made to select from different districts and latter, the population was sub grouped into two categories namely police officers and non-police officers for easy data analysis and interpretation.

Police training school administrators were selected because of their experience in the administration of the training programmes on a daily basis, instructors were included in the study to give their input on the content, materials used, assessment and instructional strategies during the programme delivery whether they enable police officers participation in the social transformation in Uganda. Graduates who participated in this study were selected with a view to find out from them if the content, methods and assessment techniques used during initial police training enable them to fully participate in the environmental sustainability awareness. District leaders, members of the community and community leaders were selected for the purpose of getting independent views and opinions in the studied area.

Also District police leaders were selected in this study because they supervise the graduates of this training programme, so it was needed to find out their opinion and views in regard to the police officers participation in the social transformation of Uganda. Respondents from government departments and non-government organisations were selected because of their expertise in Gender, environment and community matters, their opinion and views on police officers participation in these areas would be useful in drawing conclusions and recommendations in this study.

Majority of the respondents were from Kabalye because it is the biggest police training school in Uganda, takes the largest number of trainees, and has the largest number of instructors, therefore it was hoped that respondents from there had better input compared to other respondents from other schools. Trainers from other training schools were included in this study due to the fact that sometimes they are transferred from or to Kabalye, recruits are sometimes distributed in these training schools. They may also be supervised by them during attachments. A summary of this is presented in Table 1 below. 
Table 1. Study Sample

\begin{tabular}{|l|l|l|}
\hline Category & No. of selected participants & Total \\
\hline Police training school administrators & $\begin{array}{l}\text { 4 from Kabalye police training } \\
\text { school and 1 from the 4 other schools }\end{array}$ & 8 \\
\hline Instructors & 25 per school & 125 \\
\hline Police graduates & 2intakes 156 from each & 312 \\
\hline $\begin{array}{l}\text { District police leaders where } \\
\text { police training schools are located. }\end{array}$ & 5 per district & 25 \\
\hline $\begin{array}{l}\text { Members of community where } \\
\text { police training schools are located }\end{array}$ & 4 Per district & 20 \\
\hline $\begin{array}{l}\text { District leaders where police } \\
\text { training schools are located. }\end{array}$ & 4 per district & 20 \\
\hline $\begin{array}{l}\text { Community leaders where police } \\
\text { training schools are located }\end{array}$ & 4 per district & 20 \\
\hline $\begin{array}{l}\text { Government ministries and } \\
\text { departments from the national headquarters }\end{array}$ & 2each from 5 ministries and departments & 10 \\
\hline $\begin{array}{l}\text { Non-government organizations } \\
\text { from the national headquarters }\end{array}$ & 2 each from 5 Non-Government Organizations & 10 \\
\hline Total & & $\mathbf{5 5 0}$ \\
\hline
\end{tabular}

Source: Self constructed by the researcher

This sample was selected basing on their role, experience, contribution and involvement in PTPs and participation in, ESA promotion at various levels in Uganda. Some have worked with police in, ESA others participate in police training programmes planning, design, development and facilitation yet others are mandated to promote ESA.

\subsection{Sampling Techniques}

The researcher employed the following sampling techniques, Snowball, random, purposive and convenience sampling. This was due to the fact that the study population was heterogeneous of which one technique could not have given accurate results. Respondents from government ministries and departments as well as non-government organisations were purposively selected according to their roles in ESA. This included the police training school administrators. District local leaders and district police leaders where police training schools are found were also purposively selected as such because of their observation and perception of the PTPs.

A cohort of two intakes namely2010 and 2014 that had gone through the same curriculum were selected to participate in this study. There are also one hundred members from public who were selected especially from Government and Non-Government Organizations which deal with environmental related issues to participate in this study. The researcher hoped that these were better positioned to make a just and rationale case on police in the studied variable.

Respondents from the cohort of intake 2010 and 2014 were selected using Snowball technique; one respondent could guide the researcher or assistants where intake mates are deployed and could be followed from there and be served the questionnaires after gathering at 
least ten in number at the station out of those deployed at the station. Instructors were also selected using Snowball technique after visits at the training schools, one could direct where the colleague is or call him/ her to come using telephones and the researcher could serve the questionnaire to him/ her.

Community leaders were randomly selected; the researcher could approach any resident of the area and ask for the name of the community leaders in that community. After identify them the researcher or any of the assistants could choose any of them to fill the questionnaire .Some members of public who had filled the questionnaires also participated in Focused Group Discussions (FGDs) to make more clarifications on issues that had been got from the questionnaires and needed more clarifications and in-depth understanding. . Members of community were conveniently sampled. The researcher picked any member of the community so long as was in the district where police training schools are found and could read and write.

\subsection{Instruments}

Instruments used to collect data included two Questionnaires. One for police officers and another one for non-police officers. The instrument for police officers had likert's scale as a tool which had rankings of strongly agree (5), agree (4), strongly disagree (3), disagree (2), and not sure (1). This tool also had surveys as tool on which police officers had to indicate what police has done or should do in the studied areas. Likert's scale sought quantitative data while survey tools sought qualitative data. The questionnaire for non-police officers had survey scales only. Other methods used to collect data were Interviews, observational evaluation, documentary analysis and FGDs.

\subsection{Questionnaire}

This study used two questionnaires, one for police officers and another one for members of public. (Appendix A and B) .The questionnaire for police officers was divided into three sections, section one sought respondents' background/ characteristics. The second section had statements to which respondents' were expected to show their levels of strongly agree (5), agree (4), strongly disagree (3), disagree (2), and not sure(1) in relation to police training programmes and police officers participation in ESA. The third section had questions to which respondents' had to state what police has done or should do in relation to ESA in Uganda. This was meant to determine respondents, attitude, opinion, judgment and perceptions on the influence of police training programmes on the ESA in the stated areas in terms of content, methods of delivery, instructional aids, time allocated, assessment methods, and instructors' capability to impart knowledge, understanding, skills, attitude and behavior in the studied areas among others.

The questionnaire for police officers sought information on what police has done and what police should do to prevent gender based violence, promote environmental sustainability awareness and good police-community relations in Uganda. Questionnaire to the members of public sought their assessment and perception on what police officers have done in ESA in Uganda. It also focused on their suggested approaches to ESA in Uganda by police officers. 
Questionnaires were adopted in this study because the researcher wanted to gather information from a large number of police graduates and respondents' from members of public about the influence of police training programmes on social transformation in Uganda. The researcher also hoped that questionnaires were cost efficient and could give him speedy results given the time frame and meager resources the researcher had. The researcher also believed that Questionnaires will provide him with clarity on issues related to the influence of police training programmes on social transformation in Uganda, will provide anonymity to the respondents and would cover most of the aspects of the influence of police training programmes on social transformation in Uganda.

Later, the statements from the questionnaire were sub grouped into performance and training. Strongly agree and agree were presented as agree whereas strongly disagree and disagree responses were presented as disagree. A total of $60 \%$ and above was regarded as satisfying and needed to be uphold whereas $59 \%$ and below was regarded as unsatisfying and needed improvement. Only the majority percentage was presented.

The questionnaire for members of public had two sections to which they were expected to state their demographic characteristics, what police has done and what police should do to enable ESA in Uganda. It sought qualitative data in the studied area because the researcher believed that members of public are not well conversant with police training programmes in Uganda.

\subsection{Interviews}

This was intended to probe further and clarify on the information given by the participant. A set of pre-planned core questions for guidance was set (Appendix C) which enabled Consistence with all the participants who were interviewed. As the interviews could progress, the interviewees were given chances to elaborate or provide more relevant information.

Interviews were used because the researcher believed that police training programmes and police participation in social transformation is a very sensitive matter which needed face to face interaction between the researcher and some district leaders, district police leaders, Police training administrators, heads of government bodies and non-government organisations, if it was to be understood in depth. The researcher also conducted telephone interviews with some police graduates because he believed that all police graduates had telephones and shared common factors as they had gone through the same curriculum. The same view was held with the interviewed members of public of sharing common factors because they played related roles in ESA.

Prior appointment could be made with the respondent to be interviewed and the researcher could reach at least ten minutes before the agreed time and stay around. This enabled the researcher to conduct the interview in a relaxed mood. The interviews could last between thirty to forty five minutes and from these interviews more useful information that had been not properly captured in the questionnaires was brought out and incorporated into the study .Later this data could be mixed with that from other sources. 


\subsection{Observational Checklist}

The researcher as a participant observer carried out observational methods of data collection and evaluation by observing how police officers were engaging in performing activities related to ESA. The researcher explored how police officers trained, how they interpreted and made sense of the training, how they participated and applied the knowledge, understanding, skills attitude and behaviors acquired during the initial training. This was done through the community policing forums in the community meetings, radio and television talk shows. The researcher also observed how they carried out arrests, recorded statements, received complaints and complainants and how they were testifying in courts of law.

Although some wanted to change their behavior when they learnt that they were being observed, it was noted that after a few visits to their work stations by the researcher, introduction and briefing from their immediate supervisors of the purpose of observation, police officers started to consider him as a supporter at their working stations and began to feel at ease with him.

\subsection{Documentary Analysis}

Documentary review analysis was used as one of the methods for data collection. Documents analyzed were obtained from training schools and stations visited. These included police curricula for the Probationer police constables and Cadet assistant superintendents' of police initial training programmes, police training manuals. Police standing orders; police Act, police strategic policing plan 2014-2019, police restructuring book by the ministry of public service and annual crime reports.

These documents were mainly related to police training, laws of Uganda and police performance. The researcher could be allowed to stay with some for two months and then return them. These documents provided useful in-depth understanding and data to the researcher about police training programmes influence on the social transformation in Uganda particularly to the variables under investigations.

The purpose of documentary analysis in this study was to provide a confluence of evidence that could breed into credible conclusions on the influence of PTPs on police officers' participation in ESA in Uganda. The researcher also wanted to find out if there is collaboration across the findings got from various data sets collected through different methods, so as to reduce the impact of potential biases in the influence of police training programmes on ESA.

The process of document analysis followed the following steps (1) creation of a list of texts to explore (2) considering how the texts will be accessed, (3) acknowledging and addressing the biases, (4) develop appropriate skills for research, (5) considering strategies for ensuring credibility, (6) knowing the data the researcher was looking for, (7) keeping in mind the ethical issues and (8) the researcher had a backup plan.

\subsection{Focused Group Discussions}

In this study, four focus groups discussions of five to eight participants were conducted with a 


\section{Mll Macrothink}

list of questions prepared as guidance for each FGD and could last between 40 to 60 minutes. Two were conducted with police officers, one with participants from Non-government organizations which promote environmental sustainability and one with participants from government departments which promote ESA The last FGDs with police officers' was meant to get more clarity and verification on matters which had been raised from other FGDs before the final thesis was written.

Participants in FGDs were purposively selected, and this helped in developing themes. The purpose of the FGDs was to gain more in-depth understanding of the influence of police training programmes on the social transformation in Uganda and how members of public view this. These questions and discussions were based on the purpose and objectives of the study on issues that had come up from the preliminary data from questionnaires, interviews, observation and documentary review which needed more clarification before a final thesis is developed and presented.

FGDs were conducted with police graduates and instructors who had participated in filling the questionnaires, community members and some staffs from government and non-government organisations. The process began by identifying the participants who had participated into filling the questionnaires. The recruitment process began through networks and contacts by use of telephones. Participants were grouped basing on dynamics and synergistic relationships among them to generate data.

At first groups were categorized according to participants who share similar characteristics such as gender, age range, ranks, education level, marital status and roles. This was intended to generate useful data. These groups were later mixed up irrespective of gender, age range, ranks, educational level, marital status and roles. This improved the quality of discussion and its outcomes.

\subsection{Validity and Reliability}

\subsubsection{Validity}

The validity of the instrument in this study was determined by using Content Validity Index. The researcher approached some lecturers from the college of Education and External studies, Makerere University to give their opinion on the validity of the instruments constructed.

$$
\mathrm{CVI}=\frac{\text { Numberofitemsdeclaredappropriate }}{\text { Totalnumberof itemsrated }}
$$

After the calculation, the content validity ratio was 0.80 , since 0.80 is close to 1.0 , the instrument was considered to be essential for collecting the data in this study. According to Taylor (2017), the content validity ratio can measure between -1.0 to 1.0.The closer to 1.0 the content validity ratio is, the more essential the object is considered to be. Conversely, the closer to -1.0 the content validity ratio is, the more non-essential it is.

\subsubsection{Reliability}

In this study, Cronbach Alpha Coefficient was used to determine the reliability of the 
instruments. The instruments were piloted with twenty police officers, ten from those who were undergoing police senior command and staff course at Bwebajja Senior Command and Staff College, ten from those who were undergoing refresher course at Kabalye police training school. Also ten members of public from Kampala were used to pilot the questionnaire for members of public. The result of Cronbach, Alpha average correlation of 0.8 of all the items in the questionnaires was obtained.

Reliability is usually expressed numerically as correlation coefficients with 0.0 signifying total unreliability and 1.0 indicating perfect reliability. Reliability coefficients (Cronbach alpha) above 0.05 are generally regarded as high and those between 0.65 and 0.85 as moderate (Laerd Statistics 2018). Therefore since the result of Cronbach alpha average correlation of 0.8 was obtained, it means that the questionnaires used in this study were moderate to give credible and reliable results.

\subsection{Data Collection Procedure}

An introductory letter was obtained from the Dean School of Education, Makerere University and from the Inspector General of Police (IGP) before proceeding to the field. Data collection methods included semi-structured interviews, focus group discussions, document review/analysis, questionnaires and participant observation. Some graduates from other Universities assisted in administering the questionnaires and also participated in FGDs.

Interviews were conducted by the researcher and were held with police administrators, district police leaders, district leaders, government and non -government organisations members who participated in this study. They were interviewed because of their busy schedules which could not enable them to have time for the questionnaires. FGDs were held with some instructors, police graduates, members of public and community leaders' after filling the questionnaires. Observation and documentary review were used to supplement the findings in the study.

The interviews, both individual and focus group interviews were recorded and transcribed. A coupled of open-ended questions were posed to which participants were required to respond and were noted by the researcher and his assistants. This brought out useful information that was closely linked to their experiences and was analyzed, compared and categorized with the results of transcription of the focus group interviews, and subsequently triangulated and interpreted to draw conclusions.

\subsection{Analysis of the Data}

\subsubsection{Analysis of Qualitative Data}

After data collection, the process of data analysis began with the categorization and organization of data in search of patterns, critical themes and meanings that emerged from the data. The purpose was to create descriptive, multi-dimensional categories that provided a preliminary framework for inductive analysis that became a higher level synthesis of the information from the qualitative data.

This started by transcribing all the recordings which were selected basing on the goals of the 
study. Transcript errors such as lack of one true reality, lack of standardized approaches, naturalism and denaturalism were avoided by spot checking of transcriptions, provision of a specific notation system and examples for transcribers to use as a guide. The researcher also read and read in order to immerse himself with the data.

Coding was done by keeping on revisiting the data with a purpose of simplifying and keeping a focus on specific characteristics of the data. At this stage the researcher identified important sections of the text and attached labels to index them as they related to a theme or issue in the data. Codes had explicit boundaries which prevented interchanging and redundancy. Efforts were made to be systematic through the entire data set while giving full and equal attention to each data item.

Themes were generated by reading again to merge related codes. This started by sorting and collating all the potentially relevant coded data extracts into themes. Searching for themes started with a few predefined codes to help in guiding the analysis by use of tables, code manuals and mind maps. A miscellaneous theme to temporary house the codes that do not seem to fit into the main themes was created.

Themes were used to present data in a concise, coherent, logic, non-repeated and interesting account. This was done after thorough modification and refining definitions of the themes. The researcher communicated the logical processes by which findings were developed in a way that is accessible to readers, which means that the claims made in relation to the data set are rendered believable and credible. Furthermore, the researcher included direct quotes from participants and extracted raw data, shared the findings with some participants with a view of ensuring the trustworthiness of the data.

Also Cuba (as cited in Elo et al 2014 and Shenton 2004), s four strategies were adopted to ensure the trustworthiness of the Qualitative data namely Credibility, Transferability, Dependability and Conformability. Audit trails and Reflexivity were also adopted for the same purpose. Credibility was ensured by adopting well known and established conventional research methods of data collection namely questionnaires, interviews, participant observation, focused group discussion and documentary review, thematic data analysis), developing an early familiarity with police culture, government bodies and non-government organisations concern with gender based violence prevention, environmental sustainability awareness and good police community relations in Uganda(preliminary visits to their headquarters and offices, studying various appropriate documents prior to the data collection, ensuring honesty of the interviewees(giving them the opportunity to refuse to participate in the interview and to withdraw from the study at any level if anybody wishes to do so) and by utilizing only highly qualified research assistants( all research assistants were graduates and above).

Transferability in this study was ensured by providing the reader with sufficient contextual information about the study (geographical location, data collection methods, number of focused group discussion, sample size among others) to decide whether the findings could be transferred to similar situations. 
Dependability was ensured through the thorough scientific planning and execution of the study and the in-depth description of the research design and the procedure followed. Conformability or objectivity was ensured by adapting a mixed method in order to reduce the effects of a single method bias that could have influenced the study and the findings.

An audit trail was ensured by keeping of the raw data, field notes, transcripts and introductory letters from the University and Police headquarters. This means that another researcher with the same data, perspectives and situations could arrive at the same or comparable, but not contradictory conclusions with this study. Reflexivity was ensured by the researcher keeping a self -critical account of the research process, which included his internal and external dialogue. This reflexive journal was used to document and record daily logistics of the research, methodological decisions, and rationale and record the researcher's personal reflection of his values, interests and insights information about self. This reflexive journal was used to keep responses from the researcher's supervisors and group discussions.

\subsubsection{Analysis of Quantitative Data}

In this study, statistical analysis of Quantitative data gathered by means of five likert, scale of strongly agree, agree, strongly disagree, disagree and not sure was analyzed by using SPSS Version 21 (IBM, 2015). Quantitative data analysis was done by developing tables, computation of corresponding percentages from the responses obtained, coding of key words and phrases in order to pinpoint common responses. Tallies and frequency counts were made and then percentages calculated. These are presented in tables to graphically represent all the categories and sub categories of the data got from the entire participants.

Five strategies were employed to ensure the quality of the quantitative data in this thesis, first, a $89.5 \%$ sample for the study which almost triples the $30 \%$ that Salkind (2012) considered to be a good representation of the population for a diagnostic survey was employed to ensure the quality of the Quantitative data. Secondly the development of the instrument in the study (likert scale) followed a rigorous development (consulting supervisors, course mates, and lecturers in the department of curriculum, College of Education and external studies, Makerere University. Also police officers in the directorate of human resource development were consulted for this purpose).

Thirdly, the face to face validity of the instrument developed basing on likert, scale was established by means of a pilot study(Collingridge, 2014, Wiley. 2010).Fourthly respondents completed the instrument in one session under supervision so that uncertainties could be clarified immediately, such as not understanding the meaning of a specific question. Finally, the content validity of the instrument was established by means of triangulation, which indicated that the results of the questionnaire and the results of the individual interviews showed convergence validity(Creswell 2009, Mcfee1992).

Mixed methods validity referred to as data legitimation by Leech et al (2011) andOnwegbuzie and Johnson (2006) was ensured in this study by employing the nine legitimation types propagated by Onwegbuzie and Johnson (2006). These are sample integration, inside-outside, weakness minimization, sequential, conversation, paradigmatic mixing, commensurability, 
multiple validities and political.

Sample integration legitimation which is referred to as the extent to which the relationship between the quantitative and qualitative sampling designs yields quality meta-inferences by Onwuegbuzie and Burke (2006) was ensured by using a large and heterogeneous sample $\mathrm{n}=550$ with various categories of respondents in the study. This limited the issue of dominance or priority of one methodological approach over other thus giving quality deductive and inductive inferences. This enabled the combination of inferences that emerged from both approaches to construct Meta-inferences. According to Tashakkori and Teddie (2008) a meta-inference is an overall conclusion, explanation or understanding developed through an integration of the inferences obtained from the qualitative and quantitative strands of a mixed method study.

Inside-outside legitimation which is the extent to which the researcher accurately presents and appropriately utilizes the insider's view and the observer's views for purposes such as description and explanation according to Onwuegbuzie and Burke (2006) was established by allowing peer review, member checking and participant review.

Weaknesses minimization legitimation which is referred to as the extent to which the weaknesses from one approach is compensated by the strength from the other approach according to Onwuegbuzie and Burke (2006) was ensured by compensating for the weaknesses in the Quantitative approach (respondents not fully understanding the questions in the instrument) by the strength of the qualitative approach (interviewers could probe responses to ensure clarity and comprehension of questions asked).This enabled the results and interpretations to remain the same.

Conversion legitimations which is referred to as the extent to which the quantitizing or qualititizing yields quality meta-inferences by Onwuegbuzie and Burke (2006) was established by counting the number of times an interviewee rated an element in the questionnaire as stating what police has done or should do and comparing these ratings with the scores obtained for each element on the likert scale. This comparison confirmed convergent validity as ratings and scores were similar. Also narrative profile formation was done for the same purpose by constructing narrative descriptions from quantitative data which collaborated with and strengthened the qualitative data.

Paradigmatic mixing legitimation, the extent to which the researcher's epistemological, ontological, axiological, methodological and rhetorical beliefs that underlie the quantitative and qualitative approaches are successfully (a) combined or (b) blended into a usable package (Onwuegbuzie and Burke (2006). This was established by avoiding the competitions associated with dualisms and took the continua. Then moderate positions were taken on each continuum. Also the researcher decided to use both view points in the study (the study had a pure qualitative part of what police has done and what should do, and a quantitative pure part on a likert scale which were based on pure assumptions).

Commensurability legitimation, which is referred to as the extent to which the meta-inferences made reflect a mixed world view based on the cognitive process of Gestalt 
switching and integration by Onwuegbuzie and Burke (2006) was established by using conventional methods of data collection and analysis. This enabled the researcher to analyze cognitively and come up with meta-inferences which went beyond the traditional view points to well informed views (third view) about police training programmes influence on the social transformation in Uganda.

Multiple validities legitimation which is referred to as the extent to which addressing legitimation of the quantitative and qualitative components of the study result from the use of quantitative, qualitative, and mixed validity types yielding high quality meta-inferences Onwuegbuzie and Burke (2006) was achieved because of the fact that appropriate strategies to ensure Quantitative, Qualitative and Mixed methods data collection and analysis were applied and achieved as described in the previous sections. This gave high quality meta-inferences than those from qualitative or quantitative data analysis alone.

Finally political legitimation, which is the extent to which the consumers of mixed methods research value the meta -inferences stemming from both the quantitative and qualitative components of a study according to Onwuegbuzie and Burke (2006) was established by including various categories of respondents in the study namely police training school administrators, instructors, police graduates, District police leaders where police training schools are located, members of community where police training schools are located, District leaders where police training schools are located, community leaders where police training schools are located, Government Ministries and Departments from the national headquarters, and Non-government organizations from the national headquarters. This provided a plural of perspectives that were used to generate results (meta-inferences) which answered important questions and provided workable solutions. Thus reducing the tensions of power and value such as ideological based conflicts which would have come with a single study method.

All in all, Triangulation is the major approach used to evaluate the outcome of this study. Focus group interviews and individual interviews were conducted with police officers and members of public based on the interview guide (Appendix C). Other methods used were participant observation (with field notes), Questionnaires and focused group discussions.

The outcomes of the focus group interviews were triangulated with questionnaires completed by the police officers as well as members of public. The views of the focused group discussions were triangulated with the questionnaire results and the observation as well as documentary review results. Thus the triangulation exercises were done at various levels to focus on the final thesis based on various perspectives. Expert evaluation was done by the two lecturers who were the researcher's lead supervisors and were regularly updated on the findings.

In this study, alternative hypothesizes were adapted instead of the Null because the researcher wanted to prove whether it is correct that there is statistical significance between PTPs and police officers participation in ESA but not to disapprove otherwise. They were tested by running a Regression analysis using Pearson's correlation coefficients. In order to assess the overall significance of the regression model for PTPs and police officers participation in ESA 


\section{Macrothink}

Environmental Management and Sustainable Development

ISSN 2164-7682

2019, Vol. 8, No. 4

in Uganda, an Analysis of Variance (ANOVA) and regression coefficients were generated.

Furthermore, in order to establish whether PTPs are predictors of police officers' participation in ESA and to determine the magnitude to which PTPs influence police officers' participation in ESA, a standard Beta and t coefficients were generated.

\subsection{Ethical Considerations}

The researcher asked for permission from the different authorities to access the information.

The researcher also explained to the participants that they were free to withdraw any time

from the study if they felt uncomfortable.

Ascription of authorship was by attributing accurately the sources used; this was used to avoid plagiarisms.

The researcher reported accurately what he found out in the study and margins of error were clearly stated in line with conventional research norms.

Participants were also assured of confidentiality and anonymity. The Thesis was written in such a way that the respondents cannot be identified.

\section{Data Presentation, Analysis and Interpretation}

\subsection{Response Rate}

Respondents comprised of Police training school administrators, Instructors, Police graduates, District police leaders, District leaders, Community leaders, Officials from Government ministries, departments \& other bodies, Non-government organizations staffs and members of the public.The study targeted 450 police officers and 100 members of public, however only 412 police officers and 80 non police officers participated in the study, giving a total of 492 respondents in the whole study, hence a response rate of $89.5 \%$.This is a good response rate and offers a reasonable ground to make a case for any recommendations or observations. Besides, Gay (1987) recommends a response rate of 50\% and above as adequate for research. In line with this study, the researcher hopes that this was an adequate representation from police and members of public to draw reliable conclusions that can be generalised in line with the influence of police training programmes on social transformation in Uganda. In addition, a high response rate is desirable in educational research because it shows the enthusiasm of the stakeholders in a particular phenomenon and offers unbiased estimates (Dillman 2000; Heberlein\& Baumgartner, 1978). 
Table 2. Response rate

\begin{tabular}{|l|l|l|l|}
\hline Response category & Targeted sample size & $\begin{array}{c}\text { Actual number } \\
\text { of respondents }\end{array}$ & Response Rate \\
\hline Police training school administrators & 8 & 8 & $100.0 \%$ \\
\hline Instructors & 125 & 111 & $88.8 \%$ \\
\hline Police graduates. & 312 & 268 & $85.9 \%$ \\
\hline District police leaders & 25 & 25 & $100.0 \%$ \\
\hline Members of public & 20 & 20 & $100.0 \%$ \\
\hline District leaders & 20 & 20 & $100.0 \%$ \\
\hline Community leaders & 20 & 20 & $100.0 \%$ \\
\hline Government agencies & 10 & 10 & $100.0 \%$ \\
\hline Non-government organisations & 10 & 10 & $100.0 \%$ \\
\hline Total & $\mathbf{5 5 0}$ & $\mathbf{4 9 2}$ & $\mathbf{8 9 . 5 \%}$ \\
\hline
\end{tabular}

Source: Primary data (2018)

\subsection{Background Characteristics of 412 Police Officers and 80 Non Police Officers}

In this section, the characteristics of the respondents that answered the questionnaires are presented. The characteristics sought were gender, age, highest academic standards, and period of service and marital status of the respondents. These characteristics were collected to assist the researcher understand whether they have a bearing to the police participation in ESA in Uganda and that data had been collected from an authentic sample as well as establishing if the characteristics are typical of the theoretical and contextual attributes already known about police officers participation in ESA.

\subsection{Gender and Age of 412 Police Officers}

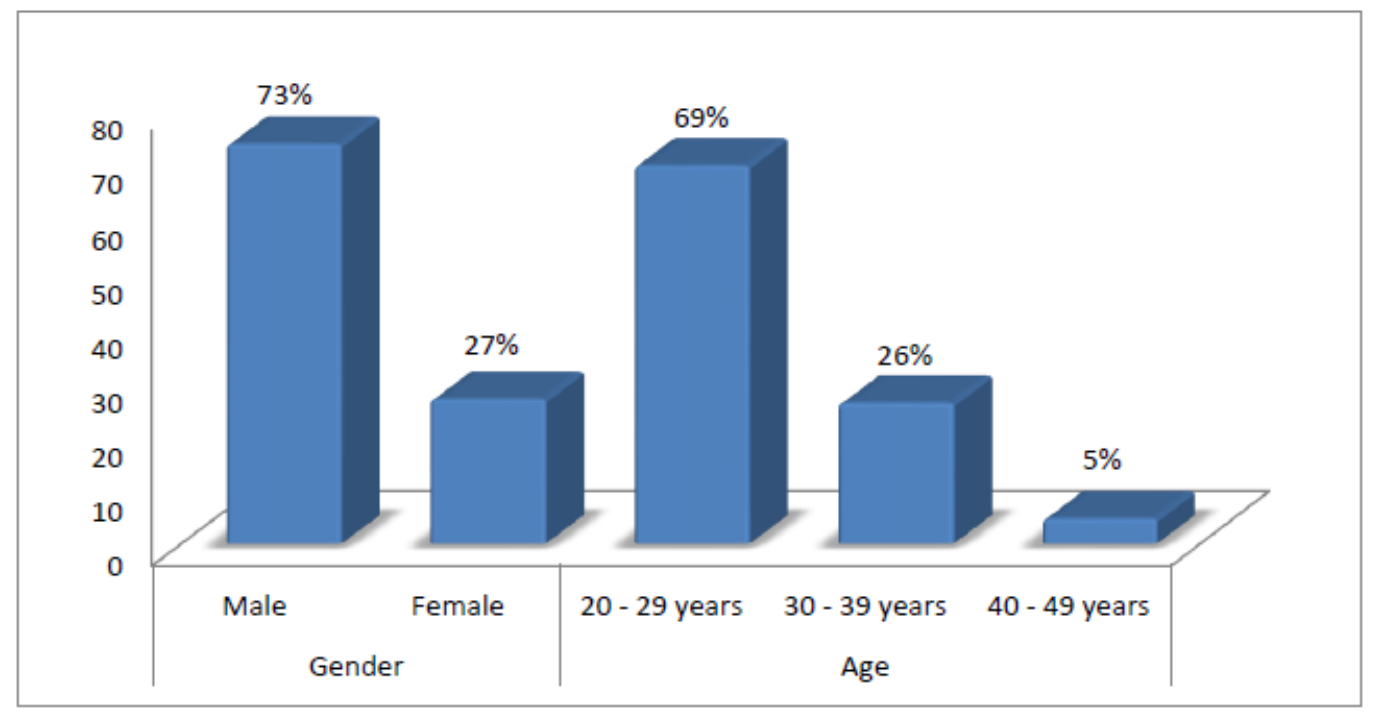

Figure 2. Gender and age of the 412 police officers who answered the questionnaire

Figure 2 above shows that the majority of the police officers, 73 percent were male as compared to 27 percent that were female. In terms of age groups, the majority, 69 percent 
were aged 20 - 29 years, whereas 26 percent were aged 30-39 years and five percent only were aged 40-49 years. This confirms the UPF Strategic policing plan 2014/15-2020 as on October 2014 that there are more male police personnel than female police personnel in UPF (5958 females compared to36752 male officers) and that majority of the personnel who participated in this study had gone through the same curriculum and are trainable. Secondary this is the age bracket where most Ugandans are facing challenges related to ESA as they are out of schools.

The respondents' demographic characteristics of members of public in terms of gender, age, highest standard of education attained and marital status were sought. This was done in the quest to establish whether these characteristics of the respondents had an impact on the data they provided to this study about the police participation in ESA in Uganda.

\subsection{Gender and Age of the Respondents from80 Non-police Officers}

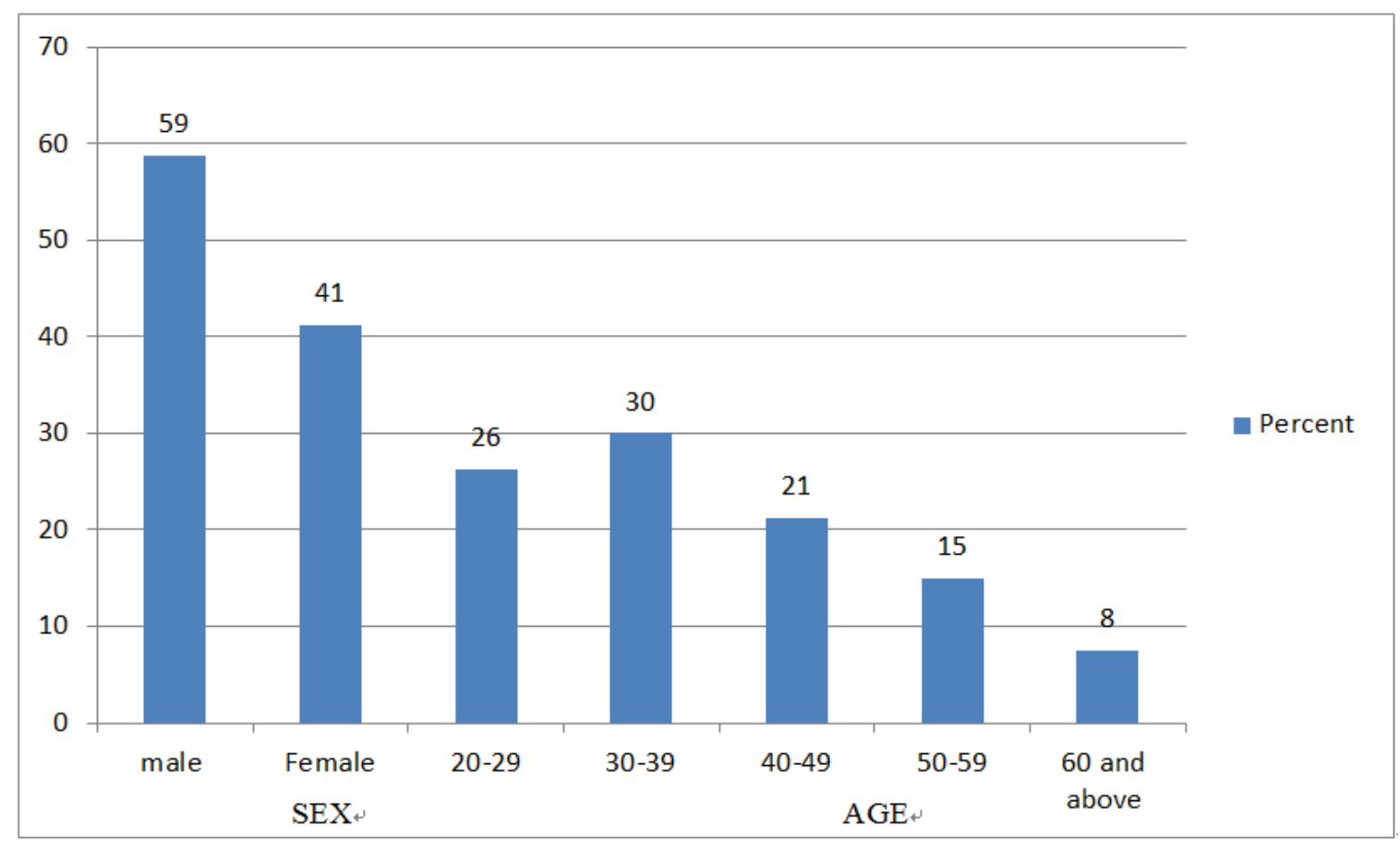

Figure 3. Gender and age of the respondents

According to the results in Figure 3 above, more than half $59 \%$ of the study respondents were male and $41 \%$ were female. Despite of the observed disparity in favor of men, the study was gender inclusive since data was obtained from both male and female members of the public. This therefore implies that the study findings can be generalized to represent views of both male and female members of the public about police participation in ESA in Uganda.

As indicated in the Figure 3, the biggest proportion $30 \%$ of the study respondents were aged between 30 and 39 years of age, followed by $26 \%$ who were aged between $20-29$ years. $21 \%$ were between $40-49$ years. $15 \%$ of the respondents were aged between $50-59$ years and the last category of 60 years and above was represented by $8 \%$. This means that data were 


\section{Macrothink}

collected from mature people who understood well the study variables. Secondly, data was collected from different age categories of the members of public. This therefore implies that the study findings can be generalized to represent the views of the public at large about police participation in ESA in Uganda.

\subsection{Highest Academic Standards of 412 Police Officers}

The highest academic standards of the police officers were sought to assess whether they have a bearing on the ESA in Uganda and the findings are shown in the pie chart.

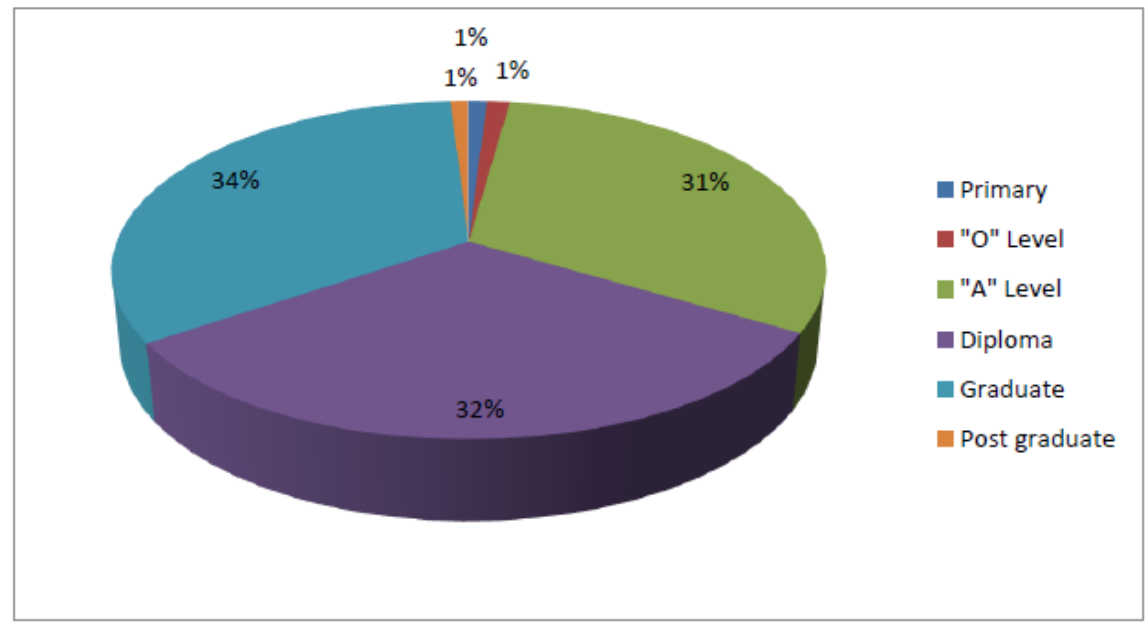

Figure 4. Highest Academic Standards

Figure 4 above show that most of the police officers possessed (Advanced level of education) "A" Level (Higher secondary education level (31\%), Diploma (32\%) or Graduate (34\%) levels of education. Respondents with Primary, (ordinary/ senior secondary school) "O" Level or Post graduate levels of education were of negligible numbers. This means that the majority of respondents understood issues related to PTPs and police officers participation in ESA and are trainable as they had attained a reasonable level of education.

\subsection{Highest Standard of Education Attained by 80 Non Police Officers}

The respondents were asked about their highest standard of education to ascertain whether this had an impact on their knowledge about the police participation in ESA in Uganda and results are presented in the figure 


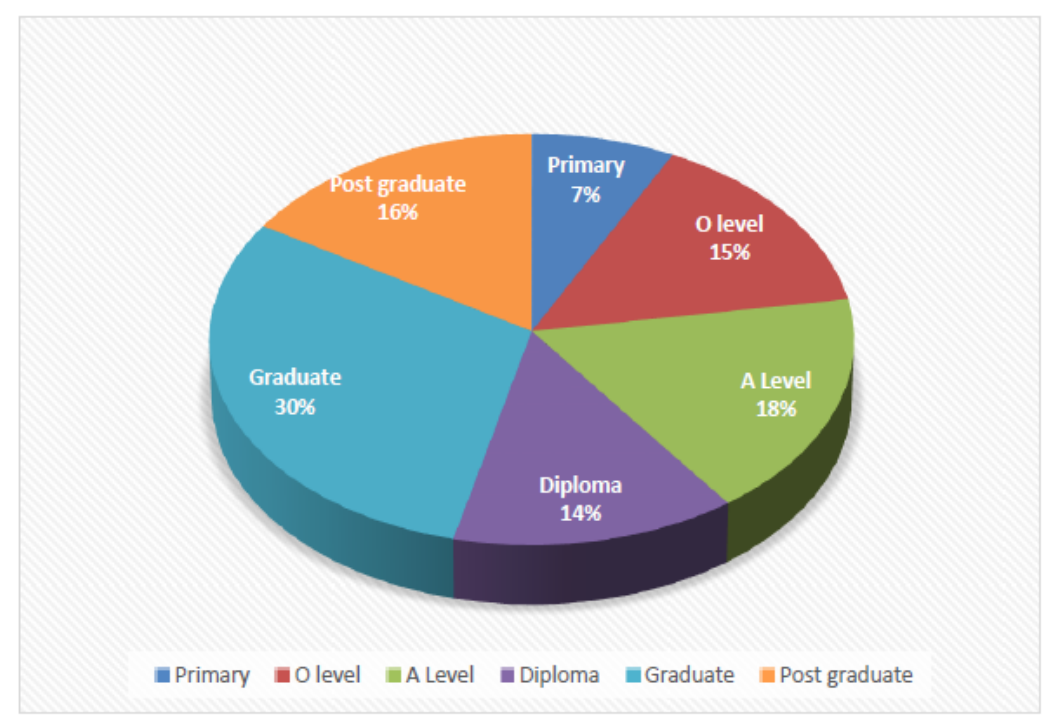

Figure 5. Highest academic standards

The findings in Figure 5 indicate that most $30 \%$ of the study respondents were educated up to degree level, followed by $18 \%$ who were educated up to Advanced level, then by $16 \%$ who had attained post graduate qualification, then by $15 \%$ who had finished Ordinary level, then $14 \%$ who had attained diploma qualifications and lastly by $14 \%$ who were educated up to primary level. This shows that data was attained from respondents of different education categories. This implies that the views of the general public were well represented in the study.

\subsection{Marital Status and Period of Service of412 Police Officers}

The marital status and period of service in the Uganda Police service by the respondents were also collected to assess whether they have a bearing on ESA in Uganda and the findings are shown in the pie chart. 


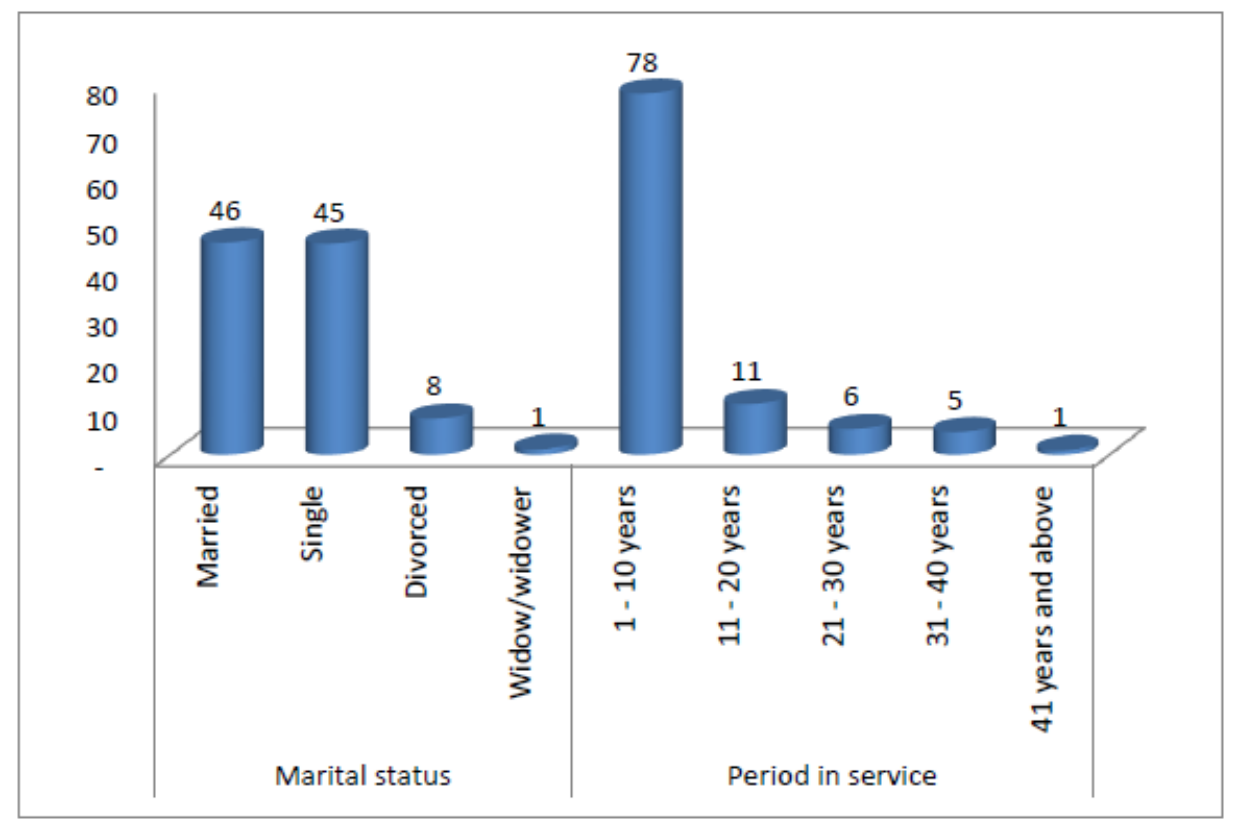

Figure 6. Marital Status and Period in Service

Figure 6 above shows that police officers that were married (46 percent) were almost equal in number to those that were single (45\%), whereas the divorced constituted eight percent only and the windows/widowers comprised one percent only. In terms of period in service, the majority 78 percent had served between $1-10$ years, while 11 percent has served $11-12$ years and those that had served over 20 years were generally negligible in number. This means that majority of the respondents had experience to better apply personnel knowledge, understanding, skills, attitude and behavior on issues related to PTPs and police officers participation in ESA as they had gone through the same current curriculum. Questionnaire for members of public only sought their opinions and views on what police has done and what should do in the studied areas.

\subsection{Marital Status of 80 Non Police Officers}

The marital status of the respondents was captured and this was intended to assess whether this had an impact of the views that they gave about the police participation in ESA in Uganda. Results are presented in the chart. 


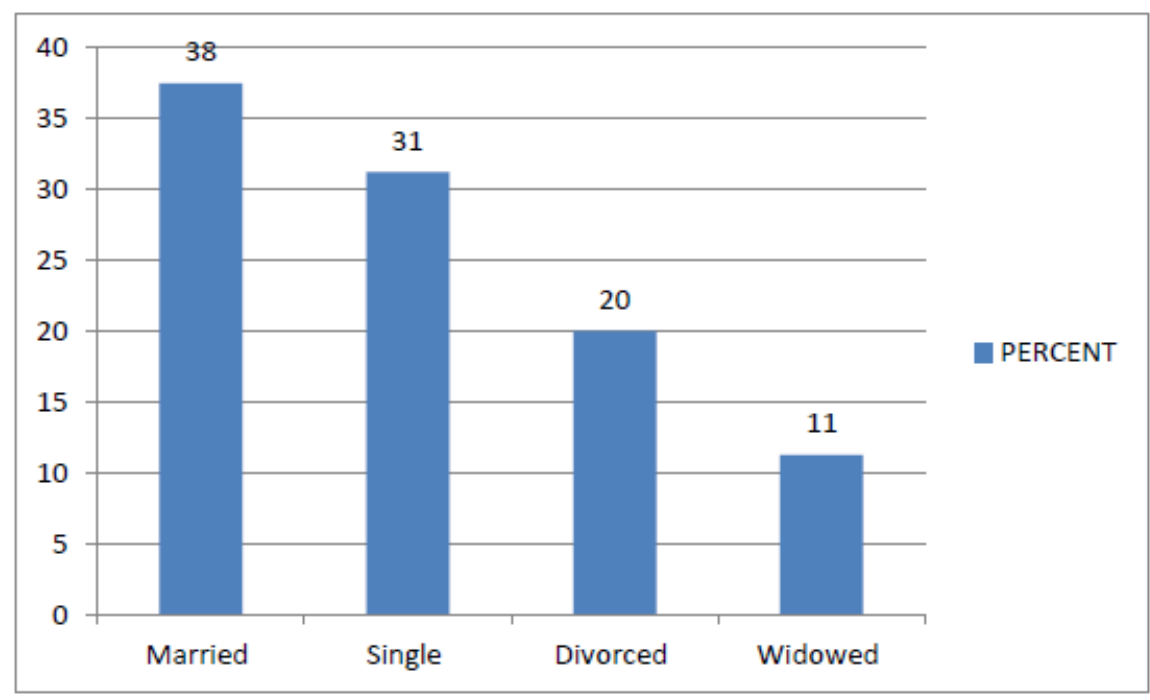

Figure 7. Marital status of the respondents from non-police officers

The findings in Figure 7 indicate that most $38 \%$ of the study respondents were married, $31 \%$ were single, $20 \%$ were either divorced or separated from their partners and lastly $11 \%$ were widowed. This shows that data was obtained from all the categories and this implies that it was free of marital bias and can be used to represent the views of the general public about police participation in ESA in Uganda.

\subsection{Hypothesis: Police Training Programmes Influence Police Officers Participation in Environmental Sustainability Awareness in Uganda}

The above Hypothesis was guided by the question. How do police training programmes influence police officers participation in environmental sustainability awareness in Uganda?, In order to understand the views of the respondents on training programmes, so as to establish whether they have influence on police officers' participation in ESA to the community in Uganda, the study used fourteen statements on the questionnaire to which the respondents were required to show their level of agreement or disagreement.

The quantitative findings from the respondents that answered the questionnaires are presented in Table 3. 
Table 3. Police officers provision of ESA to the community in Uganda

\begin{tabular}{|l|l|l|l|l|l|}
\hline Statements & \multicolumn{3}{l|}{ Percentages } \\
\cline { 2 - 5 } & SA & A & D & SD & NS \\
\hline Training & & & & & \\
\hline $\begin{array}{l}\text { Initial Police Training Programmes have enough Training and Learning Aids on } \\
\text { Environmental Sustainability in Uganda }\end{array}$ & 14 & 37 & 43 & 6 & 0 \\
\hline $\begin{array}{l}\text { Police Training programmes (curriculum) in Uganda cover Environmental } \\
\text { Sustainability content adequately }\end{array}$ & 15 & 38 & 38 & 6 & 3 \\
\hline $\begin{array}{l}\text { Police Trainers cover content in the curriculum on Environmental Sustainability } \\
\text { adequately }\end{array}$ & 15 & 38 & 37 & 8 & 2 \\
\hline $\begin{array}{l}\text { Time allocated to cover Environmental Sustainability laws during the initial Police } \\
\text { Training programmes in Uganda is enough for the subject to enable participation in } \\
\text { ESA }\end{array}$ & 15 & 42 & 34 & 7 & 2 \\
\hline $\begin{array}{l}\text { The assessment methods during initial police training programme facilitated } \\
\text { learning on environmental sustainability }\end{array}$ & 11 & 42 & 37 & 7 & 3 \\
\hline $\begin{array}{l}\text { The training methods during initial police training programmes facilitated learning } \\
\text { on environmental sustainability }\end{array}$ & 9 & 43 & 42 & 3 & 3 \\
\hline $\begin{array}{l}\text { The instructional strategies during initial police training programme facilitated } \\
\text { learning on environmental sustainability }\end{array}$ & 10 & 42 & 41 & 4 & 3 \\
\hline Performance & & & & & \\
\hline $\begin{array}{l}\text { Police Officers enforce laws related to Environmental Sustainability in Uganda after } \\
\text { initial training programmes. }\end{array}$ & 5 & 51 & 38 & 4 & 2 \\
\hline $\begin{array}{l}\text { Police Officers promote Environmental Sustainability awareness in Uganda after } \\
\text { initial police training programmes }\end{array}$ & 7 & 49 & 36 & 4 & 4 \\
\hline $\begin{array}{l}\text { Police Officers themselves do Environmental Sustainability in Uganda after initial } \\
\text { training programmes }\end{array}$ & 6 & 57 & 33 & 4 & 0 \\
\hline $\begin{array}{l}\text { Police Officers need more Training on Environmental Sustainability Laws in } \\
\text { Uganda }\end{array}$ & 4 & 55 & 35 & 4 & 2 \\
\hline $\begin{array}{l}\text { Police has enough resources to enforce Laws related to Environmental sustainability } \\
\text { in Uganda }\end{array}$ & 16 & 36 & 35 & 10 & 3 \\
\hline Witnesses in Environmental crimes are protected by police in Uganda & 9 & 55 & 26 & 8 & 2 \\
\hline $\begin{array}{l}\text { Police officers have knowledge, understanding, skills, attitude and behavior to } \\
\text { handle cases related to Environmental sustainability violation in Uganda }\end{array}$ & 10 & 56 & 27 & 6 & 1 \\
\hline
\end{tabular}

Source: Primary data (2018)

When police officers were asked on their participation in ESA to the community in Uganda, the responses in Table 3 above were got:

\subsection{Training}

Training was one of the dimensions used to measure police officers' provision of ESA to the community in Uganda and the findings are here under presented. Strongly agreed and agree responses are both presented as agree, whereas strongly disagreed and disagree responses are both presented as disagreed to generally compare those that agreed to those that disagreed.

Table 3 further shows that the majority, $51 \%$ were of the view that initial Police training programmes have enough training and learning aids on environmental sustainability in Uganda; $14 \%$ strongly agreed and $37 \%$ agreed. This posits that the some training materials on environmental sustainability awareness during police training are available. 
On whether Police training programmes in Uganda cover environmental sustainability adequately, the majority, $53 \%$ agreed; $15 \%$ strongly agreed and $38 \%$ agreed. This means that more should be done during police training programmes to cover environmental sustainability.

On the issue of whether Police trainers cover environmental sustainability adequately, the majority, $53 \%$ agreed; $15 \%$ strongly agreed and $38 \%$ agreed. This means that police trainers cover environmental sustainability but not adequately during police training.

On whether the time allocated to cover environmental sustainability laws during the initial Police training programmes in Uganda is enough, the majority, 51\% agreed; $15 \%$ strongly agreed and 34\%agreed. This means that there is time allocated to cover environmental laws during police training but is not enough.

In order to find out further whether environmental related laws are taught during police training, an interview was held with a police training administrator at Kabalye Police Training School and had this to say

"During police training, environment is one of the subjects on the curriculum here".

In order to find out what police should do to promote environmental sustainability awareness in Uganda, an interview was held with an official from a government department and said that "police officers should be trained more on global and regional laws; treaties; protocols and declarations related to environmental protection and be provided with enough funds in order to perform their duties effectively". When probed further to state or mention some of these global and regional laws, traties, protocols and declarations that police officers should know, the official mentioned the following "(1) .millennium declaration.. 2000, (2) Convention on Biological Diversity,. 1992,(3) Alchi Biodiversity Targets 2015- 2020, (4) UNESCO Convention on Cultural and Natural Heritage. 1992, (5) United Nations Convention to Combat Desertification. 1994, (6) The United Nations Framework Convention on Climate change. 1992, with its Kyoto protocol, (7) Hyogo Framework 2005 - 2015 and its successor, the Sendai Framework for Disaster Risk Reduction 2015- 2030."

This officer also mentioned the following global and regional laws, treaties, protocols and declarations to be taught to police officers during their initial police training in Uganda (1) The Convention on Wetlands of International importance (Ramar Convention). 1971, (2) Convention on International Trade in Endangered species of wild fauna and flora, (3) Lusaka Agreement on cooperative Enforcement operations directed at illegal trade in wild Fauna and Flora, (4) IUCN Red list of Threatened Species 1994 (first version was 1991), (5) UNESCO Convention on safe guarding Intangible heritage . 2003, (6) UNESCO Convention on the protection and promotion of the diversity of cultural expressions. 2005, (7) Stockholm Convention on persistent organic pollutants. 2001, (8) Johannesburg Declaration on Sustainable Development .2002, (9) Montreal Protocol on substances that deplete the Ozone layer.

Furthermore, this officer mentioned other global laws, treaties, protocols and declarations that should be taught to police officers in Uganda during initial police training if they are to 
effectively participate into environmental sustainability awareness and these were : (1) Amendment to the Montreal on substances that Deplete the Ozone Layer, (2) Rotterdam Convention on the prior informed consent procedure for certain Hazardous Chemicals and Pesticides in International trade.1998, (3) Convention on the International Maritime Organisation.1948, (4) Statute of the International Renewable Energy Agency. 2009, (5) Cartagena Protocol on Bio - safety. 2003, (6) East African Community Protocol on Environmental and Natural Resources / EAC Memorandum of understanding on the environment, (7) Common Market for East and Southern Africa (COMESA) Treaty , (8) Greater Virunga Trans boundary Collaboration. 2015, (9) The Arusha Declaration on Regional Conservation and Combating Wildlifel Environmental Crime, (10) The United Nations Sustainable Development Goals. 2030 and (11) the African Union Agenda 2063”.

In a related interview with a head of programme in a Non-Government Organisations dealing with environmental related issues said "police officers should get more training on regional and international laws on matters related to environmental sustainability and even the police budget should focus on environment matters"

On the issue of whether the assessment methods during initial police training programme facilitated learning on environmental sustainability, the majority, 53\% agreed; $11 \%$ strongly agreed and $42 \%$ agreed. This means that the assessment methods during police training programmes in Uganda do not fully facilitate learning on environmental sustainability.

On whether the training methods during initial police training programme facilitated learning on environmental sustainability, the majority, 52\%; 9\% strongly agreed and 43\% agreed. This implies that the training methods during police training programmes in Uganda do not fully facilitate learning on environmental sustainability.

Finally on whether the instructional strategies during initial police training programme facilitated learning on environmental sustainability, the majority $51 \%$ agreed; $10 \%$ strongly agreed and $41 \%$ agreed. This means that the police training instructional strategies in Uganda during police training programmes do not fully facilitate learning on environmental sustainability.

\subsection{Performance}

Performance was one of the dimensions used to measure police officers' participation in ESA to the community in Uganda and the findings are hereby presented. Strongly agreed and agree responses are both presented as agree, whereas strongly disagreed and disagree responses are both presented as disagreed to generally compare those that agreed to those that disagreed.

Table 3 show that majority of the respondents, 56\% were of the view that Police Officers enforce laws related to Environmental Sustainability in Uganda; 5\% strongly agreed and 51\% agreed. This means that police training programmes influence police officers to enforce laws related to environmental sustainability in Uganda but not adequately.

Similarly the majority, $56 \%$ were of the view that Police Officers promote environmental 
sustainability awareness in Uganda; 7\% agreed and 49\% strongly agreed. This means that police training programmes influence police officers to promote environmental sustainability awareness in Uganda but not adequately.

On the issue of whether Police Officers participate in environmental sustainability awareness in Uganda, the majority, 63\% agreed; 6\% strongly agreed and 57\%agreed. This implies that police training programmes influence police officers to participate in environmental sustainability awareness in Uganda.

On whether Police Officers need more training on environmental sustainability Laws in Uganda, the majority, 59\% agreed; $4 \%$ strongly agreed and 55\% agreed. This suggests that police officers should get more training on laws related to environmental sustainability in Uganda.

On whether Police has enough resources to enforce laws related to environmental sustainability in Uganda, the majority $52 \%$ agreed; $16 \%$ strongly agreed and $36 \%$ agreed. This confirms that there are resources allocated to police to enforce laws related to environmental sustainability in Uganda but are not enough. During the data collection the researcher expenditure work plan for the second quarter of financial 2016/17 and there was some money allocated to Environmental Protection Police Unit as operational fund.

When police officers were asked what police has done to ensure ESA in Uganda, responses' were generated under the following thematic themes;

1. Environment is one of the topics under police curricula at initial courses.

2. Police has established a department/unit to specifically handle environmental related crimes.

3. Police partners with other government departments like those under Justice, Law and Order Sector and Non- Government Organisations to handle environmental related crimes and matters.

4. Police does community policing on ESA on Radios, Televisions, New papers and other media.

When police officers were asked what police should do to ensure Environment sustainability. The following thematic themes were developed.

1. Police should review its curricula to make environment an independent module and develop its manuals.

2. Operationalize the environment protection unit to the lowest police establishments.

3. More funds are allocated to activities related to environment protection activities and enforcement in police.

4. Police should advocate for an independent division in the directorate of public prosecution and the judicially to handle environmental related crimes so that environmental related crimes are handled faster in courts.

Regarding community environmental awareness, the majority of the respondents from public acknowledged the creation of the Environmental Protection Unit in the Uganda Police Force. 
Respondents noted that the police has been carrying environmental awareness campaigns through media channels and community meetings. Respondents commended the fact that Uganda Police Force has arrested and caused prosecution of perpetuators of environmental crimes and acknowledged that police officers have participated in the environmental protection campaigns by planting trees to restore the environmentally degraded land.

The respondents from members of public noted that Uganda Police Force should not only deploy environment protection unit officers to the lowest police establishments to enforce environmental laws but also advocate for efficient funding from the government to deal with the environmental issues within the lowest levels of the community. Respondents also noted that the police should step up the efforts of sensitizing the communities about the need to conserve the environment and also to work with the judiciary to speed up the process of solving environmental related crimes.

In order to find out further how police ensures community environmental awareness and sustainability, an interview was held with a police district leader and had this to say

"Police has a zero tolerance policy to desertification and ensures environmental gases are treated. The Police Force also encourages tree planting by police men and women. The force is also routinely involved in creating public awareness on the dangers of environmental degradation in the entire country".

In a FGD with seven police officers on the same view one said that "environmental related laws were among those topics we studied but were not exhaustive compared to what we are faced with in the field during our routine work".

Table 3 further shows that on the issue of whether witnesses in environmental sustainability cases are protected by Police in Uganda, the majority 64\% agreed; 9\% strongly agreed and 55\%agreed. This indicates that police training programmes in Uganda influences police officers to protect Witnesses in cases related to environmental issues.

On whether Police officers have knowledge, understanding, skills, attitude and behavior to handle cases related to Environmental sustainability violation in Uganda, the majority 63\% disagreed; $7 \%$ strongly disagreed and $56 \%$ disagreed. This suggests that police training programmes do not influences police officers knowledge, understanding, skills, attitude and behavior to handle cases related to environmental sustainability violations in Uganda.

During the data collection, in order to find out further if environmental sustainability is among the areas taught during police training programmes, the researcher reviewed several documents such as the Curriculum books for C/ASPs, PPCs(2015), these revealed that environmental related topics are included in the curriculum but fragmented in various modules.

Another document reviewed during this study was the Restructuring of the UPF by Management services Department, Ministry of public service (2015); this revealed that there is creation of Directorates, Departments and Units which deal with environmental sustainability awareness issues. These include Directorate of fire and rescue services, 
Departments like Environmental protection police, Tourism police, Agriculture police, Marines police, and Oil \& Gas protection police among others. Also UPF Strategic Policing Plan 2015/16-2019/20 was reviewed during this study. This revealed that, the UPF strategic policing plan 2015/16-2019/20 on environment sustainability awareness is envisioned in the following strategic actions/interventions ;(a)construction of 17 new marine detaches office blocks and accommodation facilities, (b) Induction, advanced and specialized training for marine officers. (c) Completion of the police marina facility at Kigo and construction of police docking facilities for border waters (L. Victoria, Edward\& L. Albert), (d) Equipping of the Marine police with boats, assortment of marine operation equipment, salvage/ rescue tools and equipment, sets of communication system and vehicles, (e) Automating marine policing system (including assorted ICT requirements and 30 solar systems), (f)Establishment of marine training school, ( $\mathrm{g}$ ) set up special police units for Agriculture and fisheries as well as specialized training of 500 police officers for these units.

Although environment is covered in the training curriculum, environmental police protection units and some other directorates and departments are not yet operationalized in the lowest unit of the police establishment -the police post, this affects police services to the community.

During the visit at National Environment Management Authority (NEMA), the Environmental Police unit office was in the same building at NEMA head office. This suggested that there was good coordination between police and NEMA on environmental issues. The same was observed at National Forestry Authority (NFA) with a liaison police officer. Marines police unit as well as oil and gas units were all operational.

In Kabalye police training school the researcher observed that the compound was covered with green grass, trees, and the toilets were clean. Further inquiries revealed that the trees, the forest near the school and the grass in the compound were planted by police trainees of 2007intake.Still at Police Senior Command and Staff College Bwebajje, similar things were observed which were planted by the first intake 01/2016 as well as Ikafe, Olilim and Kibuli police driving school. This implied that police officers practiced what they learned environmental issues right from training.

An observation of some of the library books revealed that most books were on legislation, a further critical observation of the list of facilitators/ resource persons revealed that few of them had formal environment, natural sciences or science related education background. Majority had formal education in law and other fields. This implied that more text books on environmental related issues needed to be supplied to police training schools and trainers with environmental education background be posted to training schools.

All police stations and barracks visited during the study period had trees, green compounds , clean toilets, running sewerage systems and garbage collection points despite of the buildings being old. No littering of rubbish was seen, each homestead had its own sizeable dust bin which it could take to the barrack centralized garbage collection point. From this point could be taken away to a gazette point by a central body either by municipalities or town councils. This suggested that police officers in Uganda are mindful about environmental issues. 


\section{Macrothink}

Environmental Management and Sustainable Development

ISSN 2164-7682

2019, Vol. 8, No. 4

At Nsambya police barracks, the researcher observed a cesspool truck moving with a Ugandan police number plate emptying the filled toilets. This meant that the UPF leadership in Uganda support environmental sustainability.

\subsection{Correlation Analysis for Police Training Programmes and Police Participation in ESA}

In order to measure the degree and direction of the relationship between training in environmental awareness and participation in environmental sustainability activities Pearson's product-moment correlation coefficient was calculated and the results are presented in Table 4 below.

Table 4. Correlation matrix for police training programmes and police participation in environmental sustainability awareness

\begin{tabular}{|l|l|l|l|}
\hline \multicolumn{2}{|l|}{ Study Variables } & $\begin{array}{l}\text { Training } \\
\text { programmes }\end{array}$ & $\begin{array}{l}\text { Participation in environmental } \\
\text { sustainability awareness }\end{array}$ \\
\hline \multirow{3}{*}{ Training programmes } & Pearson Correlation & 1 & $.587^{*}$ \\
\cline { 2 - 4 } & Sig. (2-tailed) & & .000 \\
\cline { 2 - 4 } & $\mathrm{N}$ & 412 & 412 \\
\hline \multirow{2}{*}{\begin{tabular}{l} 
Participation in $\begin{array}{l}\text { environmental } \\
\text { sustainability awareness }\end{array}$ \\
\cline { 2 - 4 }
\end{tabular}} & Pearson Correlation & $.587^{*}$ & 1 \\
\cline { 2 - 4 } & Sig. (2-tailed) & .000 & 412 \\
\hline
\end{tabular}

*.Correlation is significant at the 0.05 level (2-tailed).

Table 4 shows that there is a moderate positive relationship between training programmes and participation in environmental sustainability awareness, $(\mathrm{r}=0.587, \mathrm{p}=0.000, \mathrm{n}=412)$. The relationship is statistically significant at $95 \%$ confidence level since p-value (Sig.) is less $0.050(=0.000)$. This means that improvements in Training programmes during the training of police officers shall lead to improvements in participation in environmental sustainability awareness. Similarly decline in training programmes during the training of police officers shall be related to decline in participation in environmental sustainability awareness.

\subsection{Regression Analysis for Training Programmes and Participation in Environmental} Sustainability Awareness

Regression analysis was used to establish the influence of training programmes on police officers provision of environmental awareness in Uganda and this was guided by the following hypothesis:

\section{Hypothesis: Police training programmes influence police participation in environmental sustainability awareness.}

The coefficient of determination ( $\mathrm{R}$ Square) one of the statistics under regression analysis is presented in Table 5 below.

Table 5. Model Summary

\begin{tabular}{|l|l|l|}
\hline $\mathrm{R}$ & R Square & Adjusted R Square \\
\hline $0.587^{\mathrm{a}}$ & 0.344 & 0.343 \\
\hline
\end{tabular}


a. Predictors: (Constant), Training programmes

Table 5 shows Pearson's correlation coefficient $(\mathrm{R}=0.587)$, Coefficient of determination or $\mathrm{R}$ Square of 0.344 and Adjusted R Square of 0.343. An adjusted R Square of 0.343 means that Training programmes accounts for $34.3 \%$ of the variance in police officers participation in environmental awareness in Ugand $a$. This means that when other factors are inserted in the regression model the magnitude of influence may change. Therefore training programmes with environmental sustainability content is one of the many factors that influence environmental awareness in Uganda.

To assess the overall significance of the regression model for training programmes and police officers participation in environmental awareness in Uganda, Analysis of Variance (ANOVA) and regression coefficients were generated and the results are presented in the table 4.5 below.

Table 6. ANOVA and regression coefficients for training programmes and participation in environmental awareness in Uganda

\begin{tabular}{|l|l|l|l|l|l|l|}
\hline ANOVA & \multicolumn{3}{l|}{ Coefficients } \\
\hline Model & Df & F & Sig. & Standardized Beta Coefficient & T & Sign \\
\hline Regression & 1 & 215.368 & $.000^{\mathrm{b}}$ & 0.587 & 14.675 & .000 \\
\hline
\end{tabular}

a. Dependent Variable: Participation in environmental sustainability awareness

b. Predictors: (Constant), Training programmes

In determining whether a regression model is significant, the decision rule is that the calculated p-value (level of significance) for ANOVA must be less than or equal to 0.05. Since the calculated p-value of 0.000 is less than 0.05 , the regression model was found to be statistically significant $(\mathrm{F}=215.368, \mathrm{df}=1, \mathrm{p}<0.05(=0.000))$. This means that training programmes have a statistically significant influence on police officers participation in environmental sustainability awareness in Uganda.

Furthermore to establish whether training programmes are predictors of police officers participation in environmental awareness and determine the magnitude to which training programmes influence police officers participation in environmental awareness, Standardized Beta and t Coefficients were generated. For the magnitude to be significant the decision rule is that the $t$ value must not be close to 0 and the p-value must be less than or equal to 0.05 . Since the t-value of 14.675 isn't close to 0 and p-value $<0.05(=0.000)$, the study confirmed that training programmes are predictors of police officers participation in environmental sustainability awareness. A standardized Beta coefficient of 0.587 means; every 1 unit increase in training programmes with environmental sustainability content will lead to an increase of 0.587 units of police officers participation in environmental sustainability awareness.

Research findings from correlation analysis established that training programmes with environmental sustainability content have a moderate positive statistically significant relationship on police officers participation in environmental awareness. Findings from regression analysis confirmed that training programmes with environmental sustainability 
content have a statistically significant positive influence on police officers participation in environmental awareness. Therefore the research question; How do police training programmes influence police participation in environmental sustainability awareness in Uganda, was answered as follows:Every 1 unit increase in training programmes with environmental sustainability content will lead to an increase of 0.587 units of police officers participation in environmental awareness.

Furthermore, the hypothesis that was stated as thus; "Police training programmes influence police officers participation in environmental sustainability awareness" was accepted.

\section{Discussion}

\subsection{Influence of Police Training Programmes on Police Officers Provision of Environmental Sustainability in Uganda}

The objective of this study was to establish the influence of police training programmes on police officers provision of environmental sustainability awareness to the community in Uganda. In the study, environmental sustainability awareness was conceptualized as land resources, water and wetland resources, atmospheric resources, and energy and mineral resources.

The study findings, correlation analysis established that there is a strong positive relationship between training programmes and participation in environmental sustainability awareness, $(\mathrm{r}=0.848, \mathrm{p}=0.000, \mathrm{n}=412)$. Findings from regression analysis revealed that training programmes have a statistically significant influence police officers participation in environmental awareness in Uganda (Adjusted R Square $=0.718$ ). This means that training programmes accounts for $71.8 \%$ of the variance in environmental awareness. These results mean that improvements in training programmes would result to improvements in growth of environmental sustainability awareness and that police training programmes influence police officers participation in environmental sustainability awareness, $(r=0.848, p=0.000, n=412)$, ( Adjusted R square=0.718) suggesting that training programmes account for $71.8 \%$ of the variance in environmental sustainability awareness.

The qualitative findings further confirmed that environmental related issues is among the areas covered during initial police training programmes, This finding is in line with the UN(2014) finding that in Africa, Central Asia, Asean Countries and China enforcement of the environmental laws and regulations can be through civil enforcement. This civil enforcement includes (a) tools, equipment and training, (b) procedures, (c) awareness and public engagement, (d) information sharing and knowledge management, (e) alternative dispute resolution.

Also this study found out that police officers in Uganda enforce laws related to environmental sustainability awareness. This finding is in line with the UN (2014) findings that in Africa, Central Asia, Asean countries and China criminal enforcement is among the ways to ensure environmental sustainability awareness. Criminal enforcement is done through (a) institutional coordination/collaboration, (b) tools, equipment training and information sharing and knowledge management, (c) awareness and public engagement,(d) procedures in the 
criminal law, and (e) remedies (criminal sanctions and penalties).This finding further collaborated with Gunningham(2011) finding in U.S.A that environmental regulations must be well designed, efficiently and effectively enforced.

In addition, the study revealed that police officers in Uganda need more training on environmental related issues. This finding is in agreement with Stravoot and Rawang (2016) in Thailand who found out that most police officers needed to obtain the environmental education to inspire their empowerment before performing the enforcement law. This finding further agreed with Wunderlich (2017) findings that in China environmental protection bureau has limited power, the police structure is complex, the structure of environmental governance in China is fragmented .These impede inter-departmental cooperation, low levels of public participation, and lack of capacity and personnel.

Furthermore, it was found out that the police environmental protection unit works closely with NEMA and other government and non-government -organisations agencies dealing with ESA in Uganda. The study further revealed that police officers participate in activities that promote ESA on Radios, Televisions, Newspapers, in the barracks, and even in the training schools. These findings were in collaboration with the UN (2014) findings that in Africa, Central Asia, Asean Countries and China, administrative enforcement of environmental laws includes (a) institutional coordination/collaboration, (b) information sharing and knowledge management, (c) tools, equipment and training,(d) awareness and public engagement.

The above findings further agreed with Brennan (2016) findings in Northern Ireland on the enforcement of waste law; deterrence, damping and the dynamics of devolution that a significant shift in enforcement culture and practice in Northern Ireland is necessary in order to ensure enforcement action against waste criminals. These findings also collaborated with Cao and Shao (2017) findings that strengthening and improving the environment law enforcement mechanisms is an important way to protect the ecological environment. The findings were also in agreement with Alm and Shimshack (2014) findings in U.S.A that deterrence alone cannot explain all patterns of environmental behavior suggesting for both traditional and additional tools.

The consistence in findings could have been because of the methodology used to collect and analyze the data such as questionnaires, interviews, observation, documentary analysis and FGDs. Data analysis included both qualitative and quantitative methods of data analysis. These findings were upheld by the researcher because police needs multiple approaches to influence environmental sustainability awareness in Uganda.

The agreement was caused by the time frame in which all the studies took place, all the studies took place almost within five years in which environmental challenges are related globally. The researcher upheld the findings and arguments as they seemed to be good practices and could yield better results if adopted and implemented by the UPF.

\subsection{Conclusion}

The findings revealed that training programmes with environmental sustainability content have a moderate positive statistically significant relationship on police officers participation 
in environmental awareness, that training programmes with environmental sustainability content have a statistically significant positive influence on police officers participation in environmental awareness and that training programmes with environmental sustainability awareness content are predicators of police officers participation in environmental awareness sustainability It was concluded that improvements in training content, materials used, assessment strategies and instructional strategies would have a positive influence on environmental sustainability in terms of; police officers participation in environmental sustainability awareness in Uganda, for example they carry out community policing on Radios, Televisions, Newspapers and even other forums; Police officers enforcement of laws related to environmental sustainability by arresting, investigating, prosecuting and even testifying in courts of law against suspects in environmental issues. They also partner with other stakeholders like National Forest Authority, NEMA, JLOS members to ensure that the environment is sustained; establishment of some Units within police to deal directly with ESA, these units include the Environmental Protection police Unit and Agriculture police unit; Police officers are also encouraged to ensure clean environment in the barracks, by planting trees while in training schools; police officers also participate communal activities that promote ESA in Uganda like communal cleaning.

However it was also concluded that training programmes were facing a number of challenges such as underfunding, inadequate curricula, and insufficient instructional and assessment methods, unsatisfying learning and training environments, insufficient time, insufficient training aids and infrastructures among others.

\subsection{Recommendations}

1. The Uganda Police Force Management should commit adequate and sustained resources to environmental sustainability awareness to enable standardization and non-conventional methods of training The Uganda Police Force should develop monitoring mechanisms to ensure their effective implementation and oversight.

2. Police officers should be trained on communication skills, sign language, French and Arabic. This will enable them to effectively participate in environmental sustainability awareness through community policing and law enforcement.

\section{Acknowledgements}

This study would not have been possible without the grace of God and several other people who helped me. The great people who deserve my special thanks are my two lead supervisors: Associate Professor B. Ezati and Dr. W.S. Wafula of the College of Education and External Studies, Makerere University. I thank them for coming through this process with me. I thank them for always being available for me without any condition, timely and encouraging responses. My humble prayer is that they continue living so as to inspire all other students who pass through their capable hands. I thank my dear wife Sseggiriinya Suzan Onjia and children Apeta favour, Sseggiriinya Emmanuel Gombe, Sseggiriinya Esther Kirabo and Sseggiriinya Elizabeth Tendo for the social and economic endurance when I was pursuing this course. 
I wish to greatly appreciate all other people who dedicated their valuable time and effort to help and guide me through this study. Iam particularly indebted to Prof. Mugimu, Prof. Mugagga, Prof. Kagoda, Assoc. Prof.Bisaso, Dr. Onen,AssociateProf.Mulumba Mathew,Dr. Genza, Dr. Musisi,Dr. Nambi and Dr. Ndawula Stephen. Their counseling and encouragement made a big difference to the study and my life as a whole, if it was not their professional counseling and encouragement, it would have been difficult for me to complete this course. I thank Mr.Mpoza Joseph Mary of KyalusoweMasaka who educated me from senior one to University. I would also wish to acknowledge Mr. Kasolo Moses and Rev. Sister Justine Namagandafor the work and discussions we did together, I would like to thank the management and students of Dagharmasold hall for providing me with enabling environment for reading and discussions. Last but not least, I would like to thank my late parents Mr. and Mrs.Ssemujju Peter of Nalubobya- Kiwambya, Nakasongola District for bringing me up in a humble way and whatever they did for me which has enabled me to be what I am now. May they rest in eternal peace.

\section{References}

Alm, J., \& Shimshack, J. (2014). Environmental Enforcement and Compliance, Lessons from Pollution, Safety and Tax settings. Journal of Environmental Law, Stanford Environmental Law Journal, 26, 317-2. https://doi.org/10.1561/0700000048

Brennan, C. (2016). The enforcement of Waste Law in Northern Ireland: Deterrence, Dumping and the Dynamics of Devolution. Journal of Environmental Law, 28(3). https://doi.org/10.1093/jel/eqw026

Cao, H., Shao, H., \& Cai, X. (2017). Analysis of Environmental Law Enforcement Mechanisms Based on Economic Principles. School of Management, environmental science, Ocean University, China. https://doi.org/10.1088/1755-1315/94/1/012188

Chowdbury, M. F. (2014). Interpretivism in Aiding our Understanding of the Contemporary social World. Journal of Philosophy. https://doi.org/10.4236/ojpp.2014.43047

Cohen, J. (1988). Statistical Power Analysis for the Behavioral Sciences. $2^{\text {nd }}$ Edition.Routledge.

Cohen, J. (1992).Sample size.

Collingridge, K. (2014). Medelling risk areas in the North sea for blooms of the invasive comb Jelly. Mnemoiphsisleidyia. Agassiz, 1865. https://doi.org/10.3391/ai.2014.9.1.02

Creswell, J. (2009). Research design Qualitative, Quantitative, and mixed methods approaches $\left(3^{r d} e d\right)$, thousand Oaks, CA Sage.

Denham, T. (2008). "Police reform and Gender and security sector reform tool kit, eds

Dillman, D. A. (2000). Survey research .Sage Publications.

Gay, L. R., \& Airasian, P. (2003). Educational Research: Competencies for analysis and application. $\left(7^{\text {th }}\right.$ Ed). Upper Saddle River NJ: Pearson Education. 


\section{Macrothink}

Environmental Management and Sustainable Development

ISSN 2164-7682

2019, Vol. 8, No. 4

Gay, L. R. (1996). Education Research: Competencies for Analysis and Application. (5ED). Prentice-Hall, Inc.Upper Saddle River, New Jersey, U.S.A.

Gunningham, N. (2011). Enforcing Environmental Regulations. Journal of Environmental law, 23(2), 169-201. https://doi.org/10.1093/jel/eqr006

Herbertein, R. V., \& Baumgartner, M. (1978). State farm Mut. Art. Ins. Co Justia, Us Law, 35650. $2^{\text {nd }} 400$.

Konstantin, F., \& Prabash, E. (2012). Interpretivism and positivism (Ontological and Epistemological perspectives. New Castle Business School. NorthumbiaUniversity. U. K.

Krejcie, R. V., \&Morgan, D. W. (1970). Determining sample size for resesarch activities. Chowdbury. https://doi.org/10.1177/001316447003000308

Laerd, B. P. (2018).Cronbach’s Alpha@Using SPSS Statistics.

Mugagga, R. (2016). Mukajanga: The royal executioner caught between rock and hard place. Daily Mosnitor News Paper of Uganda.

Mukisa, F. (2013). Abambowa: The men who protect the Kabaka. Daily Monitor News Paper of Uganda.

Onwuegbuzie, A. J., \& Johnson, R. B. (2006). The Validity Issue in Mixed Research. Mid-South Educational Research Association, 13(1), 48-63.

Opolot, J. S. E. (1983). Preliminary Assessment of the Uganda Police Training Needs. Sage Journals. https://doi.org/10.1177/0032258X8305600408

Paul, D. W. (2012). Security studies: an introduction. Abingdon, rout ledge

Salkind, N. J. (2012). Exploring research.( $8^{\text {th }}$ ed). Upper Saddle River, NJ: Prentice Hall.

Stapleton, T. (2015). Police and Policing. https://doi.org/10.1093/obo/9780199846733-0024

Statistics Solutions. (2019). Sample Size Formula.

Stravoot, B. K., \& Rawang, W. (2016). Intergration of environmental Education and Environmental Law Enforcement for police officers. (Mahidol University, Salaya, Thailand, 11(12), 5698-5709.

Tashakkori, A., \& Teddlie, C. (2006). Validity issues in mixed methods research: Calling for an integrative framework. Paper presented at the annual meeting of the American Educational Research Association, San Fransisco, CA.

Taylor (2017). How to calculate Content Validity Ratios. Bizfluent.

UN, (2014). Enforcement of Environmental law: Good practices from Africa, Central Asia, Asean countries and China.

UPF (2018). The Uganda Police Force Gender Policy (2019-2023), Towards a More Gender Responsive and Effective Police Force. 
UPF. (2006). The Historical Profile of the Uganda Police Force (1906-2006), Unpublished. UPF. (2006). The Historical Profile of the Uganda Police Force (1906-2006), Unpublished.

Walker, S. (1977). A critical history of police reform: the emergency of professionalism, Texton MT: texton Books. pp. 1453.

Wisdom, J., \& Creswell, J. W. (2013). Mixed Methods: Integrating Quantitative and Qualitative data collection and analysis while studying patient-centered medical home models. AHR Publication No 13.0028-EF.

Wunderlich, M. (2017). Structure and Law Enforcement of Environmental Police in China. Cambridge Journal of China Studies, 12(4).

https://doi.org/10.17865/CAM.21535

\section{Appendix}

APPENDIX A

\section{QUESTIONNAIRE FOR SAMPLED POLICE OFFICERS}

SECTION A: Back ground information

$\begin{array}{ccc}\text { 1. Gender: } & \text { Male } & \text { Female } \\ & 1 & 2\end{array}$

2. Age:

(1) $20-29$ years

(2) 30 - 39 years

(3) 40 - 49 years

(4) $50-59$ years

(5) 60 and above.

3. Highest academic standard attained

(1) Primary

(2) "O" level

(3) "A" level

(4) Diploma

(5) Graduate

(6) Post graduate

4. Period of service

(1) $1-10$ years

(2) $11-20$ years

(3) $21-30$ years

(4) $31-40$ years

(5) 41 and above.

5. Marital Status

Married (2) Single (3) divorced (4) widow/widower

SECTION B: 
i) The content of initial Police Training Programmespromotesmy participation in community environmental Sustainability awareness.

ii) The content of initial Police Training programmesenablesme to enforce laws on environmental Sustainability

iii) The content of initial Police Training programmes enables participation in environmental Sustainability

iv) Police Officers enforce laws related to Environmental Sustainability in Uganda.

v) Police Officers promote Environmental Sustainability awareness in Uganda

vi) Police Officers participate in Environmental Sustainability in Uganda.

vii) Police Officers need more Training on Environmental Sustainability Laws in Uganda

viii) Police has enough resources to enforce Laws related to Environmental sustainability in Uganda

ix) Initial Police Training Programmes have enough Training and Learning Aids on Environmental Sustainability in Uganda

x) Police Training programmes in Uganda cover Environmental Sustainability adequately

xi) Police Trainers cover Environmental Sustainability adequately

xii) Time allocated to cover Environmental Sustainability laws during the initial Police Training programmes in Uganda is enough

xiii) Witnesses in Environmental sustainability cases are protected by police in Uganda.

Xiv) Police officers have knowledge, understanding, skills, attitude and behavior to handle cases related to Environmental sustainability violation in Uganda.

$\mathrm{Xv}$. The assessment methods during initial police training programme facilitated learning on environmental sustainability

Xvi. The training methods during initial police training programme facilitated learning on environmental sustainability

xvii. The instructional strategies during initial police training programme facilitated learning on environmental sustainability.

\section{SECTION C:}

Data based on personal opinions/observations and attitudes about Initial Police Training Programmes influence on social transformation in Uganda.

(i) In your observations what community environmental awareness are provided by police

i)

ii)

iii)

iv)

v)

(ii) In your opinion what other community environmental awareness should be provided by police 
i)

ii)

iii)

iv)

v)

Thank you for your valuable contributions and time.

APPENDIX B

QUESTIONARRE FOR NON POLICE OFFICERS

SECTION A: Background information

1. Gender: Male Female

1.2

2. Age

(1) 20-29 years

(2) 30-39 years

(3) $40-49$ years

(4) $50-59$ years

(5) 60 and above years

3. Highest academic standard attained

(1) Primary

(2) “O” Level

(3) "A" Level

(4) Diploma

(5) Graduate

(6) Post graduate

4. Marital status

Married (4), Single (3), Divorced/ Separated (2) Widow/ Widower (1)

Data based on personal opinions/observations and attitudes about Initial Police Training Programmes influence environmental sustainability awareness in Uganda.

5. (a) In your observations what community environmental awareness are provided by police

b) In your opinion what other community environmental awareness should be provided by police

vi)

vii)

viii)

ix)

$\mathrm{x})$

Thank you for your valuable contributions and time.

APPENDIX C 


\section{Macrothink

\section{INTERVIEW GUIDE}

1. What is your highest academic qualification?

2. For how long have you been in service?

3. What is your marital status?

4. How does police provide community environmental awareness, In what other ways should police do this

Thank you for your valuable contributions and time.

\section{Copyright Disclaimer}

Copyright for this article is retained by the author(s), with first publication rights granted to the journal.

This is an open-access article distributed under the terms and conditions of the Creative Commons Attribution license (http://creativecommons.org/licenses/by/3.0/). 